Simone Felizardo Rocha De Souza

\title{
Onicomicoses causadas por fungos filamentosos não dermatófitos
}

Dissertação apresentada á Faculdade de Medicina da Universidade de São Paulo para a obtenção do título de Mestre em Ciências

Área de concentração: Dermatologia

Orientadora: Profa. Dra. Cidia Vasconcellos

São Paulo

2007 
Dedicatória

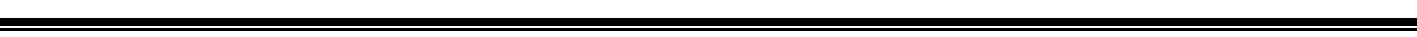


Aos meus queridos pais, Geraldo e Nilda, pelo amor incondicional. Por proporcionarem de forma tão amável os meios à minha formação profissional e principalmente humana

Ao meu marido, Fernando, pelo total envolvimento, meu companheiro e incentivador de todas as etapas deste trabalho. Mas acima de tudo pelo seu amor, e por ter me dado o maior tesouro, nosso filho Pedro.

Ao meu filho, Pedro, por ter me mostrado o real sentido da vida. 
Agradecimentos 
À minha orientadora, Profa. Dra. Cidia Vasconcellos, pela sua dedicação, amizade, bom humor e paciência durante todo o percurso. E por ter sido tão carinhosa nos momentos mais delicados.

Ao Prof. Dr. José Eduardo Costa Martins, chefe do Laboratório de Micologia do Laboratório de Investigação Médica (LIM53), por ter permitido a realização deste estudo no seu serviço.

A Natalina, Beth e Ricardo Spina, pelo grandioso auxílio no trabalho de bancada, bem como pela constante disponibilidade em ensinar, e principalmente pela amizade.

À Dona Antonia, amiga e funcionária do LIM 53 por seu especial cuidado e carinho comigo e com meus instrumentos de trabalho no laboratório.

A todos os funcionários e amigos do Laboratório de Investigação Médica (LIM53), que direta ou indiretamente estiveram envolvidos nesta pesquisa possibilitando sua conclusão, meus sinceros agradecimentos.

Aos doentes que participaram deste estudo, sem os quais, seria impossível sua realização.

A toda a minha família e a todos os meus amigos, pelo apoio e pela torcida.

A Deus, por tudo, por todos e por estar sempre ao nosso lado em todos os momentos. 


\section{Normalização adotada}

Esta dissertação está de acordo com as seguintes normas:

Referências: adaptado de International Committee of Medical Journals Editors (Vancouver).

Universidade de São Paulo. Faculdade de Medicina. Serviço de Biblioteca e Documentação. Guia de apresentação de dissertações, teses e monografias da FMUSP. Elaborado por Anneliese Carneiro da Cunha, Maria Júlia A.L. Freddi, Maria F. Crestana, Marinalva de S. Aragão, Sueli C. Cardoso, Valeria Vilhena. São Paulo: Serviço de Biblioteca e Documentação, 2004. Abreviaturas dos títulos dos periódicos de acordo com List of Journals Indexed In Index Medicus. 


\section{Sumário}


Lista de abreviaturas e siglas

Lista de símbolos

Lista de figuras

Lista de quadros e gráficos

Resumo

Summary

1. Introdução

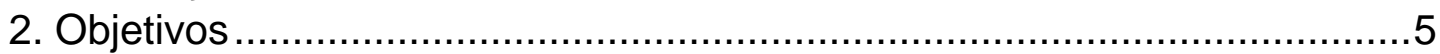

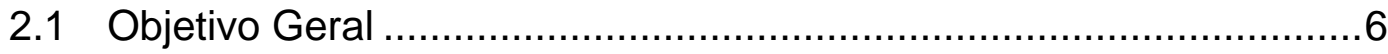

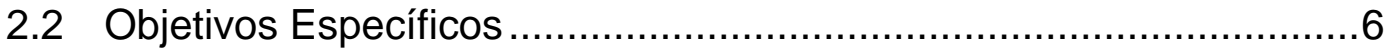

3. Revisão da literatura ................................................................... 7

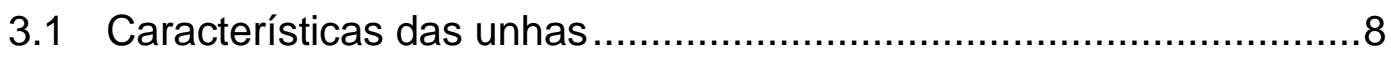

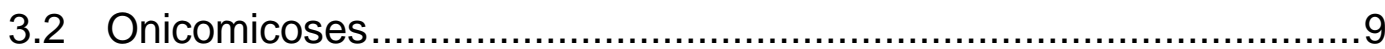

3.2.1 Agentes de onicomicoses .......................................... 12

3.2.1.1 Agentes mundiais de onicomicose ..........................14

3.2.1.2 Agentes de onicomicose no Brasil .............................15

3.3 Onicomicose por fungos filamentosos não dermatófitos ................17

3.3.1 Onicomicose por Scytalidium sp..................................17

3.3.2 Onicomicose por outros fungos filamentosos não dermatófitos ............................................................. 18

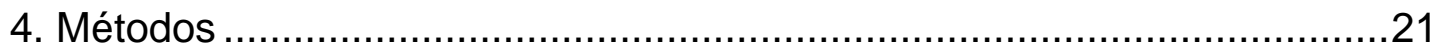

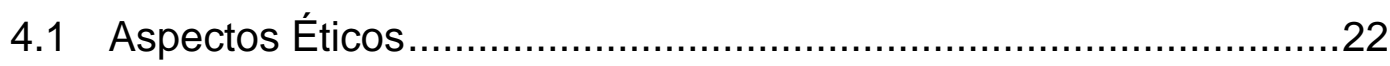

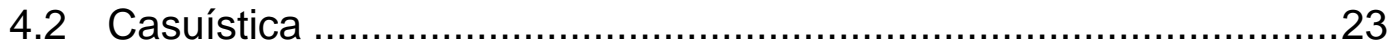

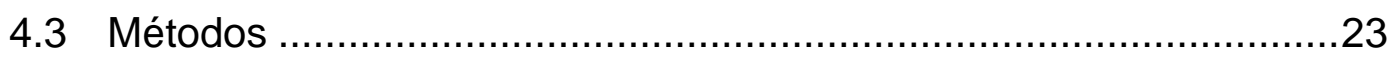

4.3.1 Meios e Técnicas Empregados ................................26

4.4 Análise Estatística ................................................................28

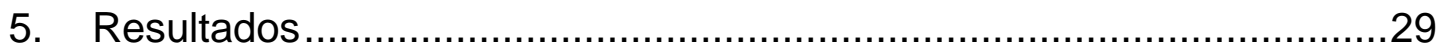

5.1 Caracterização da população geral .........................................30

5.2 Caracterização dos doentes que apresentaram exame micológico direto positivo ...................................................... 39

5.3 Caracterização dos doentes que apresentaram exame micológico direto positivo de unha e cultura para fungos negativa ..49

5.4 Caracterização dos doentes que apresentaram cultura para fungo positiva, independente do resultado do exame micológico direto

5.5 Caracterização dos doentes com onicomicose por Fungos filamentosos não dermatófitos .............................................58

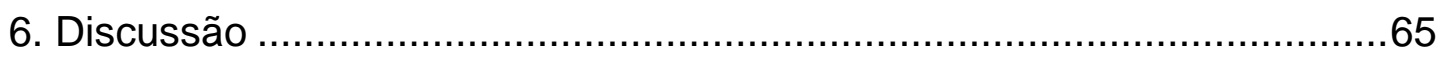

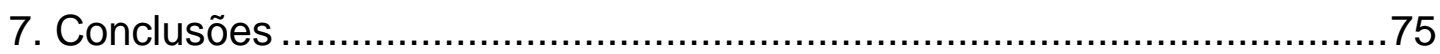

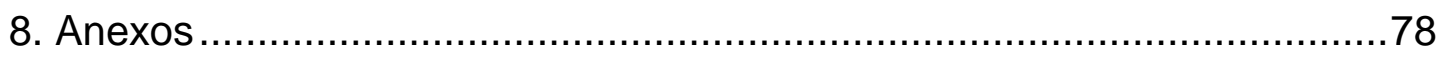

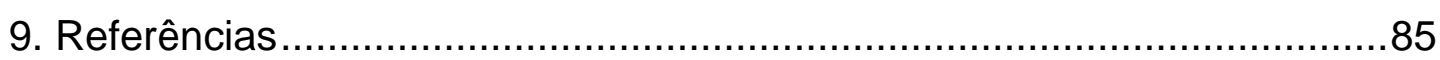


Lista de abreviaturas e siglas 


\begin{tabular}{ll} 
CAPPesq & Comissão de Ética para Análise de Projetos de Pesquisa \\
DMSO & Dimetilssulfóxido \\
et al & e outros \\
DM & Diabetes Mellitus \\
EUA & Estados Unidos da América \\
FFND & Fungos filamentosos não dermatófitos \\
HCFMUSP & Hospital das Clínicas da Faculdade de Medicina da \\
& Universidade de São Paulo \\
HIV & "Human Imunnedeficiency Virus" (virus da imunodeficiência \\
IMTSP & humana) \\
KOH & Instituto de Medicina Tropical de São Paulo \\
LIM & Hidróxido de potássio \\
MD & Laboratório de Investigação Médica \\
MOC & Exame micológico direto \\
PAS & Microscópio Óptico Comum \\
PCR & "Periodic acid Schiff " (ácido periódico de Schiff) \\
polimerase) & "Polymerase Chain Reaction" (reação em cadeia da \\
SIDA & \\
T. & Trichophyton da Imunodeficiência Adquirida \\
\hline
\end{tabular}


Lista de símbolos

Letasta de simbolos




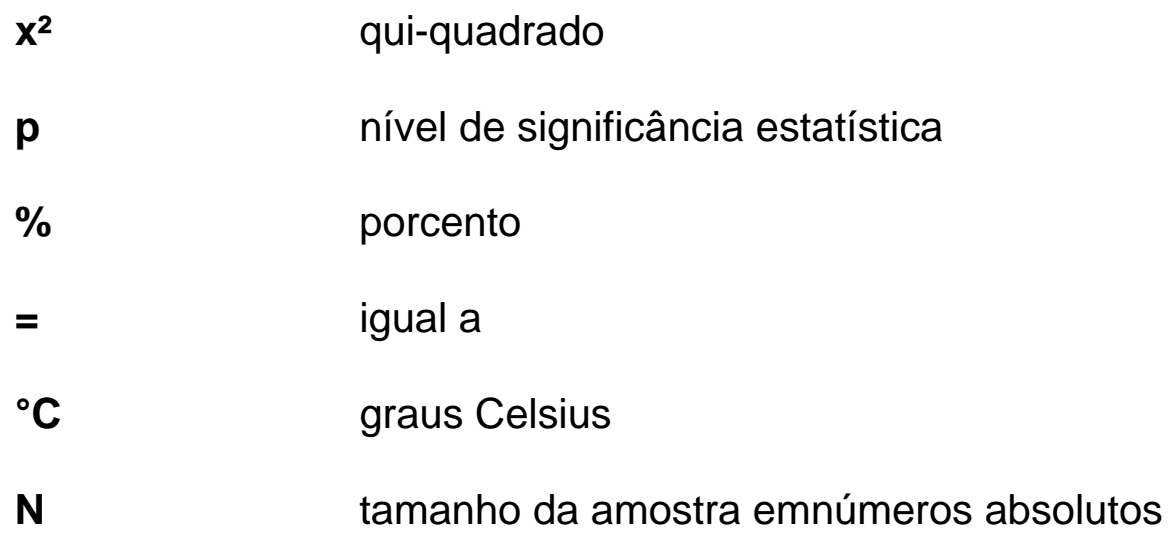


Lista de figuras e quadro 
Figura 1 - Distribuição dos doentes com suspeita clínica de Onicomicose atendidos no ambulatório de Dermatologia do HC-FMUSP, no período de dezembro de 2004 a novembro de 2005, quanto ao sexo.

Figura 2 - Distribuição dos doentes com suspeita clínica de Onicomicose atendidos no ambulatório de Dermatologia do HC-FMUSP, no período de dezembro de 2004 a novembro de 2005, quanto ao tempo de evolução da doença

Figura 3 - Distribuição dos doentes com suspeita clínica de Onicomicose atendidos no ambulatório de Dermatologia do HC-FMUSP, no período de dezembro de 2004 a novembro de 2005, quanto ao resultado do exame micológico direto.

Figura 4 - Distribuição quanto ao gênero nos doentes com onicomicose causada por fungos filamentosos não dermatófitos, atendidos no ambulatório de Dermatologia do HC-FMUSP, no período de dezembro de 2004 a novembro de 2005

Figura 5 - Quadro clínico nos doentes com onicomicose causada por fungos filamentosos não dermatófitos, atendidos no ambulatório de Dermatologia do HC-FMUSP, no período de dezembro de 2004 a novembro de 2005: onicomicose subungueal distal causada por Scytalidium lignicola - unhas dos pododáctilos apresentando hiperceratose subungueal ....

Figura 6 - Exame micológico direto de raspado de unha com hidróxido de potássio $(\mathrm{KOH})$ a $10 \%$ e dimetilssulfóxido (DMSO) a $40 \%$ nos doentes com onicomicose causada por fungos filamentosos não dermatófitos, atendidos no ambulatório de Dermatologia do HC-FMUSP, no período de dezembro de 2004 a novembro de 2005 - demonstração de artroconídios e hifas septadas de coloração ocre (400x)

Quadro - Distribuição quanto à idade dos doentes com exame micológico direto positivo, atendidos no ambulatório de Dermatologia do HC-FMUSP, no período de dezembro de 2004 a novembro de 2005 
Lista de tabelas 
página

Tabela 1 - Distribuição dos doentes com suspeita clínica de Onicomicose atendidos no ambulatório de Dermatologia do Hospital das Clinicas da Faculdade de Medicina da Universidade de São Paulo, no período de dezembro de 2004 a novembro de 2005, quanto à faixa etária

Tabela 2 - Distribuição dos doentes com suspeita clínica de Onicomicose atendidos no ambulatório de Dermatologia do Hospital das Clinicas da Faculdade de Medicina da Universidade de São Paulo, no período de dezembro de 2004 a novembro de 2005, quanto à presença de comorbidades

Tabela 3 - Distribuição dos doentes com suspeita clínica de Onicomicose atendidos no ambulatório de Dermatologia do Hospital das Clinicas da Faculdade de Medicina da Universidade de São Paulo, no período de dezembro de 2004 a novembro de 2005, quanto às unhas dos pés acometidas

Tabela 4 - Distribuição dos doentes com suspeita clínica de Onicomicose atendidos no ambulatório de Dermatologia do Hospital das Clinicas da Faculdade de Medicina da Universidade de São Paulo, no período de dezembro de 2004 a novembro de 2005, quanto às unhas das mãos acometidas

Tabela 5 - Distribuição dos doentes com suspeita clínica de Onicomicose atendidos no ambulatório de Dermatologia do Hospital das Clinicas da Faculdade de Medicina da Universidade de São Paulo, no período de dezembro de 2004 a novembro de 2005, quanto à associação com tinea pedis e/ou tinea manuum

Tabela 6 - Relação dos exames microscópicos direto versus cultivos nos doentes com suspeita clínica de Onicomicose atendidos no ambulatório de Dermatologia do Hospital das Clinicas da Faculdade de Medicina da Universidade de São Paulo, no período de dezembro de 2004 a novembro de 2005

Tabela 7 - Distribuição das culturas positivas coletadas dos doentes com suspeita clínica de Onicomicose atendidos no ambulatório de Dermatologia do Hospital das Clinicas da Faculdade de Medicina da Universidade de São Paulo, no período de dezembro de 2004 a novembro de 2005 
Tabela 8 - Distribuição quanto ao gênero dos doentes com exame micológico direto positivo, atendidos no ambulatório de Dermatologia do Hospital das Clinicas da Faculdade de Medicina da Universidade de São Paulo, no período de dezembro de 2004 a novembro de 2005

Tabela 9 - Distribuição quanto ao tempo de evolução da doença nos doentes com exame micológico direto positivo, atendidos no ambulatório de Dermatologia do Hospital das Clinicas da Faculdade de Medicina da Universidade de São Paulo, no período de dezembro de 2004 a novembro de 2005

Tabela 10 - Distribuição quanto à presença de comorbidades nos doentes com exame micológico direto positivo, atendidos no ambulatório de Dermatologia do Hospital das Clinicas da Faculdade de Medicina da Universidade de São Paulo, no período de dezembro de 2004 a novembro de 2005.

Tabela 11 - Distribuição quanto ao tipo clínico de onicomicose nos doentes com exame micológico direto positivo, atendidos no ambulatório de Dermatologia do Hospital das Clinicas da Faculdade de Medicina da Universidade de São Paulo, no período de dezembro de 2004 a novembro de 2005

Tabela 12 - Distribuição quanto às unhas dos pés acometidas nos doentes com exame micológico direto positivo, atendidos no ambulatório de Dermatologia do Hospital das Clinicas da Faculdade de Medicina da Universidade de São Paulo, no período de dezembro de 2004 a novembro de 2005

Tabela 13 - Distribuição quanto às unhas acometidas das mãos nos doentes com exame micológico direto positivo, atendidos no ambulatório de Dermatologia do Hospital das Clinicas da Faculdade de Medicina da Universidade de São Paulo, no período de dezembro de 2004 a novembro de 2005

Tabela 14 - Distribuição quanto à presença de tinea pedis e/ou tinea manuum nos doentes com exame micológico direto positivo, atendidos no ambulatório de Dermatologia do Hospital das Clinicas da Faculdade de Medicina da Universidade de São Paulo, no período de dezembro de 2004 a novembro de 2005.

Tabela 15 - Distribuição quanto à positividade da cultura para fungos nos doentes com exame micológico direto positivo, atendidos no ambulatório de Dermatologia do Hospital das Clinicas da Faculdade de Medicina da Universidade de São Paulo, no período de dezembro de 2004 a novembro de 2005. 
Tabela 16 - Distribuição quanto ao agente infeccioso por localização de acometimento ungueal e tipo clinico de onicomicose nos doentes com exame micológico direto positivo, atendidos no ambulatório de Dermatologia do Hospital das Clinicas da Faculdade de Medicina da Universidade de São Paulo, no período de dezembro de 2004 a novembro de 2005

Tabela 17 - Distribuição quanto ao tempo de evolução da doença nos doentes com exame micológico direto positivo e cultivo para fungos negativo, atendidos no ambulatório de Dermatologia do Hospital das Clinicas da Faculdade de Medicina da Universidade de São Paulo, no período de dezembro de 2004 a novembro de 2005 ....

Tabela 18 - Distribuição quanto à realização de tratamento anterior para onicomicose nos doentes com exame micológico direto positivo e cultivo para fungos negativo, atendidos no ambulatório de Dermatologia do Hospital das Clinicas da Faculdade de Medicina da Universidade de São Paulo, no período de dezembro de 2004 a novembro de 2005

Tabela 19 - Distribuição quanto à presença de comorbidades nos doentes com exame micológico direto positivo e cultivo para fungos negativo, atendidos no ambulatório de Dermatologia do Hospital das Clinicas da Faculdade de Medicina da Universidade de São Paulo, no período de dezembro de 2004 a novembro de 2005

Tabela 20 - Distribuição quanto às unhas dos pododáctilos acometidas nos doentes com exame micológico direto positivo e cultivo para fungos negativo, atendidos no ambulatório de Dermatologia do Hospital das Clinicas da Faculdade de Medicina da Universidade de São Paulo, no período de dezembro de 2004 a novembro de 2005

Tabela 21 - Distribuição quanto às unhas dos quirodáctilos acometidas nos doentes com exame micológico direto positivo e cultivo para fungos negativo, atendidos no ambulatório de Dermatologia do Hospital das Clinicas da Faculdade de Medicina da Universidade de São Paulo, no período de dezembro de 2004 a novembro de 2005

Tabela 22 - Distribuição quanto à presença de tinea pedis e/ou tinea manuum nos doentes com exame micológico direto positivo e cultivo para fungos negativo, atendidos no ambulatório de Dermatologia do Hospital das Clinicas da Faculdade de Medicina da Universidade de São Paulo, no período de dezembro de 2004 a novembro de 2005 
Tabela 23 - Distribuição quanto ao gênero nos doentes com cultivo para fungos positivo, atendidos no ambulatório de Dermatologia do Hospital das Clinicas da Faculdade de Medicina da Universidade de São Paulo, no período de dezembro de 2004 a novembro de 2005

Tabela 24 - Distribuição quanto ao tempo de evolução de doença nos doentes com cultivo para fungos positivo, atendidos no ambulatório de Dermatologia do Hospital das Clinicas da Faculdade de Medicina da Universidade de São Paulo, no período de dezembro de 2004 a novembro de 2005

Tabela 25 - Distribuição quanto à presença de comorbidades nos doentes com cultivo para fungos positivo, atendidos no ambulatório de Dermatologia do Hospital das Clinicas da Faculdade de Medicina da Universidade de São Paulo, no período de dezembro de 2004 a novembro de 2005

Tabela 26 - Distribuição quanto às unhas dos pés acometidas nos doentes com cultivo para fungos positivo, atendidos no ambulatório de Dermatologia do Hospital das Clinicas da Faculdade de Medicina da Universidade de São Paulo, no período de dezembro de 2004 a novembro de 2005

Tabela 27 - Distribuição quanto às unhas acometidas das mãos nos doentes com cultivo para fungos positivo, atendidos no ambulatório de Dermatologia do Hospital das Clinicas da Faculdade de Medicina da Universidade de São Paulo, no período de dezembro de 2004 a novembro de 2005

Tabela 28 - Distribuição quanto ao agente infeccioso por sexo e local de acometimento nos doentes com cultivo para fungos positivo, atendidos no ambulatório de Dermatologia do Hospital das Clinicas da Faculdade de Medicina da Universidade de São Paulo, no período de dezembro de 2004 a novembro de 2005.

Tabela 29 - Distribuição quanto ao tempo de evolução de doença nos doentes com onicomicose causada por fungos filamentosos não dermatófitos, atendidos no ambulatório de Dermatologia do Hospital das Clinicas da Faculdade de Medicina da Universidade de São Paulo, no período de dezembro de 2004 a novembro de 2005 
Tabela 30 - Distribuição quanto a tratamentos anteriores para onicomicose nos doentes com onicomicose causada por fungos filamentosos não dermatófitos, atendidos no ambulatório de Dermatologia do Hospital das Clinicas da Faculdade de Medicina da Universidade de São Paulo, no período de dezembro de 2004 a novembro de 2005

Tabela 31 - Distribuição quanto aos pododáctilos acometidos nos doentes com onicomicose causada por fungos filamentosos não dermatófitos, atendidos no ambulatório de Dermatologia do Hospital das Clinicas da Faculdade de Medicina da Universidade de São Paulo, no período de dezembro de 2004 a novembro de 2005

Tabela 32 - Distribuição quanto ao acometimento das unhas dos quirodáctilos nos doentes com onicomicose causada por fungos filamentosos não dermatófitos, atendidos no ambulatório de Dermatologia do Hospital das Clinicas da Faculdade de Medicina da Universidade de São Paulo, no período de dezembro de 2004 a novembro de 2005

Tabela 33 - Distribuição quanto à presença de tinea pedis e/ou tinea manuum nos doentes com onicomicose causada por fungos filamentosos não dermatófitos, atendidos no ambulatório de Dermatologia do Hospital das Clinicas da Faculdade de Medicina da Universidade de São Paulo, no período de dezembro de 2004 a novembro de 2005

Tabela 34 - Distribuição quanto à profissão nos doentes com onicomicose causada por fungos filamentosos não dermatófitos, atendidos no ambulatório de Dermatologia do Hospital das Clinicas da Faculdade de Medicina da Universidade de São Paulo, no período de dezembro de 2004 a novembro de 2005 .....

Tabela 35 - Distribuição quanto à espécie fúngica isolada nos doentes com onicomicose causada por fungos filamentosos não dermatófitos, atendidos no ambulatório de Dermatologia do Hospital das Clinicas da Faculdade de Medicina da Universidade de São Paulo, no período de dezembro de 2004 a novembro de 2005 
Resumo 
Souza SFR. Onicomicoses causadas por fungos filamentosos não dermatófitos [dissertação]. São Paulo: Faculdade de Medicina, Universidade de São Paulo; 2007. 95p.

INTRODUÇÃO: Onicomicose, infecção das unhas por fungo é a mais freqüente das doenças ungueais, constituindo aproximadamente metade de todas as alterações ungueais. Pode ser causada por dermatófitos, leveduras ou fungos filamentosos não dermatófitos. OBJETIVO: Caracterizar as onicomicoses causadas por fungos filamentosos não dermatófitos. (1) Verificar, dentre as suspeitas clínicas de onicomicose, qual a freqüência da recuperação de fungos,(2) Verificar, dentre as suspeitas clínicas de onicomicose, quais as espécies de fungos recuperadas, (3) Verificar, dentre o total das espécies identificadas, qual a freqüência das espécies de fungos filamentosos não dermatófitos. MÉTODOS: Duzentos e cinco indivíduos com suspeita clínica de onicomicose foram estudados no período de dezembro de 2003 a novembro de 2004, por meio de exames micológicos diretos e cultura para fungos. RESULTADOS: O diagnóstico de onicomicose foi estabelecido, pelo exame micológico direto, em 170 indivíduos. O diagnóstico etiológico foi estabelecido pela cultura para fungos. Dentre os 107 agentes identificados, os dermatófitos foram identificados em 78,52\% $(\mathrm{N}=84)$, as leveduras em $13,08 \%(\mathrm{~N}=14)$ e os FFND em $8,40 \%(\mathrm{~N}=9)$ das vezes. CONCLUSÃO: É necessário que se estabeleça o diagnóstico etiológico dos casos de onicomicoses, já que os fungos filamentosos não dermatófitos ocorrem com freqüência considerável e são indistinguíveis daquelas por dermatófitos.

Descritores: 1.Onicomicose 2.Fungos/patogenicidade 3.fungos/classificação 4.leveduras/patogenicidade 5.Meios de cultura/isolamento \& purificação 
Summary 
Souza SFR. Onychomycosis caused by filamentous fungi nondermatophytes [dissertation]. Sao Paulo: "Faculdade de Medicina, Universidade de São Paulo"; 2007. 95p.

INTRODUCTION: Onychomycosis, a nail fungus infection is the most frequent nail disease, constituting about half of all nail disorder. It can be caused by dermatophytes, yeasts and non- dermatophytes filamentous fungi. OBJECTIVE: Characterize the onychomycosis caused by filamentous fungi non- dermatophytes. (1) Verify after a clinical suspicion of onychomycosis, which are the frequency of fungi recovery, (2) examine, after a clinical suspicion of onychomycosis, which species of fungi are recovered, (3) Checking, among the total of identified species, which are the frequency of the species of filamentous fungi not dermatophytes. METHODS: Two hundred and five patients with clinical suspicion of onychomycosis were studied in the period from December 2003 to November 2004, through direct mycological examination and culture for fungus. RESULTS: The diagnosis of onychomycosis has been established by direct mycological examination, in 170 individuals. The etiological diagnosis was established by the culture for fungus. Among the 107 persons identified, the dermatophytes were recovered in $78.52 \%(\mathrm{~N}=84)$, the yeast in $13.08 \%(\mathrm{~N}=14)$ and filamentous fungi non- dermatophytes in $8,40 \%(\mathrm{~N}=9)$. CONCLUSION: It is necessary to establish the etiological diagnosis of the cases of onychomycosis, as filamentous fungi non- dermatophytes occur often than ever considered and are its clinic features are indistinguishable from those of the dermatophytes.

Descriptors: 1.Onychomycosis 2.Fungi/pathogenicity 3.Fungi/classification 4.Yeasts/pathogenicity 5.Culture media/isolation \& purification 
1. Introdução

1. Introduçă 
Onicomicose, ou infecção ungueal fúngica, engloba toda infecção fúngica causada por patógenos ungueais primários os quais invadem a placa ungueal saudável, e inclui aqueles que invadem a unha secundariamente em indivíduos que apresentavam doença ungueal preexistente. A invasão da placa ungueal é diferente de colonização do espaço subungueal, na qual o microorganismo está presente mas não invade a queratina ungueal (Williams, 1993).

Segundo Haneke (1991), onicomicose é a doença ungueal mais comum e constitui aproximadamente $30 \%$ das infecções fúngicas da pele. Quando comparada a outras micoses superficiais, é a mais persistente e a mais difícil de tratar (Ramesh et al, 1983)

A onicomicose tanto pode ser causada por dermatófitos (neste caso denominando-se tinea unguium), quanto por fungos filamentosos não dermatófitos, quanto por leveduras (GUPTA et al, 2003).

Os fungos filamentosos não dermatófitos (FFND) são encontrados comumente na natureza como saprófitas do solo ou como patógenos de plantas (Tostl et al, 2000). A invasão ungueal por FFND é considerada incomum, com taxa de prevalência variando de 1,45 a 17,6\% (Tosti et al., 2000). Esta variação pode refletir tanto diferenças na distribuição geográfica de tais fungos, quanto diferenças nos critérios utilizados para o diagnostico da onicomicose por FFND, ou o uso de meios de cultura não apropriados para o crescimento destes fungos (Gupta et al, 1998; Tosti et al, 2000). 
Embora vários FFND já tenham sido isolados de unhas, somente algumas espécies são identificadas como agente de onicomicose. Estes incluem Scopulariopsis brevicaulis, Fusarium sp., Acremonium sp. e Aspergillus sp., Scytalidium sp., e Onichocola canadensis (Tosti et al., 2000). Nos últimos anos, o número de casos de onicomicose causada por FFND, que até então era considerada rara, está aumentando rapidamente, sobretudo na Europa, onde são responsáveis por percentagem que varia de 1,6 a 6,0\%, de acordo com diferentes estudos (Ellis et al, 1997b).

Como as mesmas espécies de FFND podem ser encontradas como contaminante ou como agente etiológico, é necessário a confirmação do diagnóstico, pela demonstração de crescimento do mesmo agente em coletas posteriores e pela ausência de crescimento de dermatófito, também, nas repetições das culturas. A repetição da cultura positiva em duas ou mais ocasiões diferentes, na ausência de qualquer crescimento de dermatófito, reduz exponencialmente a probabilidade de que um FFND seja um contaminante (Gupta et al, 1998).

Dentre os FFND descrevem-se dois grupos de fungos: os hialinos e os demáceos. Tais fungos podem ser encontrados associados a leveduras ou a dermatófitos. Neste último caso, alguns autores consideram contaminação e outros aventam a hipótese de infecção mista (Andre \& Achten, 1987).

Até o momento, não se demonstrou que a onicomicose causada por FFND esteja significantemente associada à doença sistêmica ou que possa ser sinal de imunossupressão. Entretanto, há relato de casos de Síndrome 
da Imunodeficiência Adquirida (SIDA), nos quais dois pacientes foram a óbito devido à infecção sistêmica por Fusarium, o qual provavelmente se originou de unha infectada. Estes casos sugerem que a onicomicose por Fusarium deva ser considerada uma doença grave nos doentes imunocomprometidos (Tosti et al, 2000). 
2. Objetivos

Lagetivos 


\subsection{Objetivo Geral}

Caracterizar as onicomicoses causadas pelos fungos filamentosos não dermatófitos.

\subsection{Objetivos Específicos}

No ambulatório de Dermatologia do Hospital das Clínicas da Faculdade de Medicina da Universidade de São Paulo, no período de um ano:

1 - Verificar, dentre as suspeitas clínicas de onicomicose, qual a freqüência da recuperação de fungos, através dos exames micológico mireto (MD) e cultura;

2 - Verificar, dentre as suspeitas clínicas de onicomicose, quais as espécies de fungos recuperadas, através do cultivo de fungos in vitro;

3 - Verificar, dentre o total das espécies identificadas, qual a freqüência das espécies de fungos filamentosos não dermatófitos. 
3. Revisão da literatura

(2)




\subsection{Características das unhas}

A unidade ungueal consiste de quatro componentes epidérmicos: a matriz, que dá origem à placa ungueal, o leito ungueal, a prega ungueal e o hiponíquio (ZAIAS, 1972). Lúnula é a porção visível da matriz, em forma de meia lua, opaca e de coloração brancacenta. A dobra ungueal proximal é composta de uma superfície dorsal e outra ventral. A superfície dorsal é denominada eponíquio. A junção das duas superfícies, que se projeta distalmente sobre a placa ungueal, é a cutícula. A prega ungueal distal inclui a pele que circunda ambas as faces, lateral e proximal, da placa ungueal.

A placa ungueal é queratina morta, dura e translúcida $O$ epitélio da matriz sintetiza $90 \%$ da placa ungueal. A lúnula é a face distal da matriz ungueal e se continua com o leito ungueal. O leito ungueal se estende da matriz ungueal distal ao hiponíquio. À medida que a unha flui distalmente, material é adicionado à superfície inferior da unha, espessando-a e tornando-a densamente aderente ao leito ungueal. O leito ungueal consiste de cristas longitudinais paralelas com pequenos vasos sanguíneos em sua base. O hiponíquio é um segmento curto de pele que não apresenta adesão da unha; ele inicia no leito ungueal distal e termina na depressão distal (Zaias, 1972; Habif, 2004). 


\subsection{Onicomicoses}

A invasão da unidade ungueal por fungo é denominada onicomicose (Zaias,1992). Onicomicose é a mais freqüente das doenças ungueais, constituindo aproximadamente metade de todas as alterações ungueais (Gupta et al, 2000) e 30\% das infecções micóticas da pele (André \& Achten,1987). Estudos realizados na Espanha (Sais et al, 1995), Inglaterra (Roberts, 1992), Itália (Tosti et al, 2000), Canadá (Gupta et al, 1997; Gupta et al, 2000), Finlândia (Heikkilä et al, 1995) e EUA (Ghannoum et al, 2000), estimaram a sua prevalência em 2,6 a $13,8 \%$ da população geral. A prevalência da onicomicose aumenta nos idosos (Greer, 1995; Gupta et al, 2003). A onicomicose é observada menos freqüentemente em crianças do que em adultos, com prevalência estimada em 0,2\% por Philpot et al (1989) e por Inanir et al (2002) e 0,44\% segundo Gupta et al (1997b).

A onicomicose pode comprometer substancialmente a qualidade de vida dos indivíduos afetados (Scher,1995; Drake et al, 1999). Fatores predisponentes para onicomicose incluem idade avançada, tinea pedis, trauma ungueal repetitivo e algumas comorbidades como diabetes (Gupta et al, 2000), imunodeficiência e doença arterial periférica (Ghannoum et al, 2000). Segundo Gupta \& Konnikov (1998), o risco para a população diabética estaria aumentado em 2,77 vezes mais do que para a população geral. Romano et al (2001) não demonstraram freqüência maior de onicomicose em pacientes diabéticos em relação ao controle. 
A apresentação clínica da onicomicose causada por uma determinada espécie fúngica é indistinguível daquela causada por outras espécies. Há, porém, alguns sinais clínicos que sugerem a espécie fúngica incriminada, embora, definitivamente, o agente etiológico só possa ser determinado após a identificação laboratorial por meio do cultivo para fungos. A onicomicose superficial branca é geralmente causada por Trychophyton mentagrophytes (Zaias, 1966; Piraccini \& Tosti, 2004).

Tipos clínicos de onicomicose são definidos pelo modo como o fungo invade a unidade ungueal (Zaias,1972). Classicamente, quatro tipos de onicomicose são aceitos (Zaias, 1992):

(a) Onicomicose subungueal distal - o fungo, primeiro invade o hiponíquio e então progride para afetar o lado de baixo da placa ungueal lateral e proximal.

(b) Onicomicose superficial branca - o fungo invade somente a superfície da placa ungueal e produz "ilhas" brancas de infecção na placa ungueal.

(c) Onicomicose subungueal proximal - o microorganismo invade a unidade ungueal via dobra ungueal proximal, através da cutícula e progride distalmente. A infecção ocorre dentro da substância da placa ungueal, mas a superfície permanece intacta.

(d) Onicomicose associada à candidíase mucocutânea crônica - a placa ungueal é invadida distalmente através do espessamento total provocado pelo fungo. 
O tipo clínico de onicomicose mais comumente encontrado é o subungueal distal. Trichophyton rubrum é o agente etiológico mais freqüente. Ele geralmente invade a placa ungueal secundário a uma infecção da pele ao redor, principalmente plantar ou palmar (Hay et al, 1994).

Em pacientes portadores da Síndrome da Imunodeficiência Adquirida (SIDA), é descrita uma forma de onicomicose branca subungueal proximal, na qual a infecção progride rapidamente da margem proximal até atingir toda a unha (Dompmartin et al, 1990; Gupta et al,2000; Porro \& Yoshioka, 2000). É considerado um marcador clínico precoce de infecção por HIV (Elewski, 1998). Carvalho (1990) observou 10 casos de onicomicose branca subungueal proximal em 60 pacientes HIV soropositivos, sendo o Trichophyton rubrum o agente etiológico em todos os casos.

Há uma tendência a rotular qualquer processo envolvendo a placa ungueal como uma infecção fúngica, mas muitas outras doenças cutâneas podem alterar a estrutura da unha. Gupta et al (2000), num estudo com 15.000 pacientes, observou 2505 indivíduos com unhas anormais, destes, aproximadamente metade apresentou o diagnóstico de onicomicose. O diagnóstico diferencial da onicomicose deve ser feito com afecções que atingem as unhas como psoríase, líquen plano, infecções bacterianas, dermatite de contato, tumores ungueais, síndrome das unhas amarelas, onicólise idiopática, paquioníquia congênita e onicodistrofias traumáticas (Elewski, 1998). O exame micológico é indispensável para a diagnose e deve ser analisado com espírito critico (Sampaio \& Rivitti, 1998). 
Tradicionalmente, o exame micológico direto com hidróxido de potássio $(\mathrm{KOH})$ e a cultura para fungos são os métodos preferencialmente utilizados para o diagnóstico de onicomicose. O exame histológico de espécimes da lâmina ungueal com coloração pelo ácido periódico Schiff (PAS) é considerado um método diagnóstico complementar nos casos em que há forte suspeita clínica de onicomicose mas os exame direto com $\mathrm{KOH}$ e a cultura para fungos foram negativos (Weinberg et al, 2003). A utilização de PCR (Polymerase Chain Reaction) ainda é de uso restrito a pesquisas (Oliveira, 2001).

\subsubsection{Agentes de onicomicoses}

As onicomicoses podem ser determinadas por dermatófitos, neste caso denominando-se tinea unguium (English,1976), fungos filamentosos não dermatófitos (FFND) ou leveduras (Gupta et al., 2003). Infecções mistas são relatadas, porém raramente. Os dermatófitos encontrados nas onicomicoses são do gênero Trichophyton e Epidermophyton, raramente Microsporum (Gupta et al, 2000; Koussidou et al, 2002; Lacaz 2002). Dentre os dermatófitos, Trichophyton rubrum e Trichophyton mentagrophytes são os mais frequentemente isolados (Ghannoum et al, 2000; Koussidou et al, 2002), Epidermophyton floccosum é encontrado menos frequentemente. Trichophyton tonsurans pode ser um agente freqüente de onicomicose em áreas onde haja ocorrência de tinea capitis por endotrix de forma expressiva (Summerbell,1997). Esporadicamente têm sido isolados outros dermatófitos, 
como: Trichophyton schoenlinii (Conti-Diaz, 1964), Trichophyton verrucosum (Krosravi et al, 2001) Microsporum gypseum (Koussidou et al, 2002) Microsporum canis (Vilela et al, 1990), Microsporum racemosum (GarcíaMartos et al, 1999) e Microsporum nanum.

Dentre as leveduras, Candida albicans é a mais comumente isolada, embora seu papel como agente de onicomicose per se seja superestimado. Ela causa acometimento ungueal extenso, principalmente dos quirodáctilos, na candidíase mucocutânea crônica e em casos de exposição ocupacional a água ou umidade, mas é muito mais comumente vista como agente de paroníquia do que de onicomicose (Williams, 1993). A melhor evidência de invasão ungueal verdadeira por leveduras é vista no exame microscópico direto como pseudofilamentos e blastoconídios laterais. A presença de células leveduriformes somente, mesmo que em abundância, pode significar meramente colonização (Summerbell, 1997). As espécies mais comumente encontradas são C. albicans e C. parapsilosis (Gupta et al, 1998). Segundo Elewski (1998) o resultado da cultura deve ser interpretado com cautela, porque as unhas não são estéreis, e, portanto fungos contaminantes podem obscurecer o verdadeiro patógeno ungueal.

Gupta et al (1997) observaram que as leveduras foram o agente de $2,8 \%$ dos casos de onicomicose pedal e $50 \%$ dos casos de onicomicose dos quirodáctilos; analisando pododáctilos e quirodáctilos num só grupo as leveduras foram o agente de aproximadamente $4 \%$ das onicomicoses.

Lopes (1999) observou que $1,7 \%$ e $84,8 \%$ das onicomicoses dos pododáctilos e quirodáctilos são causadas pelas leveduras, respectivamente. 
Araújo (2003) isolou leveduras em $26,1 \%$ das onicomicoses dos pododáctilos e em 93,4\% dos quirodáctilos. Martelozzo (2005) observou que as leveduras foram o agente de $37 \%$ das onicomicoses dos pododáctilos e de $76 \%$ dos quirodáctilos . A maioria das infecções ungueais por espécies de Candida ocorrem em pacientes com candidíase mucocutânea crônica ou então como um evento secundário na paroníquia (Williams, 1993).

Martelozzo et al (2005) dizem, textualmente: “É relevante ressaltar que a presença de Candida nem sempre está associada com o desenvolvimento de onicomicose, já que está presente na microbiota normal. Cabe ao médico fazer a avaliação clínica adequada, bem como a investigação dos fatores predisponentes“.

\subsubsection{Agentes mundiais de onicomicose}

Os dermatófitos, particularmente Trichophyton rubrum e Trichophyton mentagrophytes são os agentes etiológicos da maioria das infecções (Ghannoum et al, 2000; Koussidou et al, 2002), respondendo por 90\% das infecções das unhas dos pododáctilos e por pelo menos $50 \%$ das infecções fúngicas das unhas dos quirodáctilos, até 90\%, quando excluídas as paroníquias (Gupta et al, 2003; Ellis et al, 1997b). Trichophyton rubrum é o agente etiológico mais prevalente no Canadá (Summerbell et al, 1989; Gupta et al, 2000), Grécia (Koussidou et al, 2002), Itália (Gianni et al, 2000; Tosti et al, 2000), Finlândia (Heikkilä, 1995), Colômbia (Alvarez et al, 2004), Inglaterra (Clayton, 1992), EUA (Kemna \& Elewski, 1996), Malásia (NG et al, 2002). Krosravi et al (2001), em Teheran, Iran, estudou 187 pacientes com 
suspeita de onicomicose, 97 deles apresentaram a confirmação do diagnostico por exame micológico. Os agentes mais comuns foram Trichophyton mentagrophytes, seguido por Trichophyton violaceum. Ardehali (1972) encontrou Trichophyton schoenlinii como agente etiológico mais prevalente na tinea unguium em Teheran, Iran.

Lim et al (1992) observaram Candida albicans como o agente prevalente de 100 casos de onicomicose em Singapura, porém, a maioria dos pacientes (37/39) tinha paroníquia associada, sugerindo que a infecção ungueal foi secundária a paroníquia candidiásica. Simonetti et al (2004) estudou 135 casos de onicomicose em Ancona (Itália), as leveduras foram responsáveis por $62 \%$ das infecções (Candida albicans foi a espécie fúngica mais isolada, 31/135 casos). Neste estudo, 95 pacientes apresentavam as unhas dos quirodáctilos afetadas, e 56 as dos pododáctilos. A maioria dos pacientes apresentava paroníquia.

\subsubsection{Agentes de onicomicose no Brasil}

Costa et al, 1991 num estudo comparativo entre populações do Rio de Janeiro (RJ) e Aracaju (SE) observaram que, dentre as dermatofitoses, $T$. rubrum foi a espécie predominante no Rio de Janeiro e $T$. tonsurans em Aracaju.

No Rio Grande do Sul, Lopes et al (1999) estudaram 340 casos de onicomicose, entre 1987e 1988, identificaram dermatófitos em 70\%, leveduras em 29\% e fungos filamentosos não dermatófitos em 1,4\%. 
Ruiz \& Zaits (2001) num estudo de dermatofitoses na cidade de São Paulo, observaram que a onicomicose representou $25 \%$ dos casos de dermatofitoses e que, dentre os agentes de tinea unguium, o mais encontrado foi Trichophyton rubrum (92\%) seguido por T. mentagrophytes (13\%) e T. tonsurans (6\%).

Chimelli et al (2003) em São Paulo, identificaram o agente etiológico de 655 casos de dermatofitoses entre 1992 e 2002, dentre os agentes de tinea unguium, Trichophyton rubrum foi o mais freqüente (67\%), seguido por Trichophyton mentagrophytes (18\%) e T. tonsurans (9\%).

Araújo et al (2003), no Rio de Janeiro observou que entre os casos de onicomicose das unhas dos pés, $68 \%$ eram causados por dermatófitos, $26 \%$ leveduras e $15 \%$ FFND. Dentre as unhas das mãos, as leveduras foram o agente em $93 \%$ dos casos. Considerando unhas dos pododáctilos e quirodáctilos, os dermatófitos representaram 46,5\% ( $\mathrm{N}=186)$, as leveduras 49\% ( $\mathrm{N}=196)$ e os FFND 4,5\% (N=18).

Martelozo et al (2005), dentre as onicomicoses diagnosticadas foram isolados e identificados 322 agentes etiológicos, observaram que 33,85\% das onicomicoses foram causadas por fungos dermatófitos ( $N=109$ ), 52,17\% foram infectadas com leveduras $(\mathrm{N}=168)$ e $13,97 \%$ por FFND $(\mathrm{N}=45)$.

Aquino et al (2007) encontraram Trichophyton rubrum como agente mais freqüente de tinea unguium em Porto Alegre. T. rubrum foi o principal agente etiológico de tinea unguium em Goiânia (Costa et al, 2002). 


\subsection{Onicomicose por fungos filamentosos não dermatófitos}

\subsubsection{Onicomicose por Scytalidium sp}

Scytalidium dimidiatum é um patógeno de plantas em regiões tropicais e subtropicais (Verzignassi, 2007). Scytalidium dimidiatum, no passado denominado Scytalidium lignicola, foi descrito pela primeira vez como agente de infecção humana por Gentles e Evans (1970) infectando as unhas e a pele dos pés. Uma segunda espécie, hialina de Scytalidium, S. hyalinum, foi descrita em casos similares em 1977, por Campbell \& Mulder. Estes dois fungos são agentes de dermatomicoses em países tropicais e subtropicais (Elewski, 1996). No Brasil, Lacaz et al (1999) relataram dois casos de onicomicose por Scytalidium dimidiatum em São Paulo, Araújo et al (2003) quatro casos no Rio de Janeiro, Pontarelli et al (2005) dois casos em Santa Catarina. Com poucas exceções, a ocorrência destas espécies em países temperados ocorre em pacientes com origem ou historia de viagem a países tropicais (Campbell et al, 1973; Campbell e Mulder, 1977; Moore,1986; Alvarez et al, 2000; Lacroix et al, 2003). Tais espécies de fungos são consideradas queratinolíticas (Lacaz et al, 2002), são tão capazes quanto os dermatófitos de infectar a epiderme intensamente queratinizada e as unhas (Moore, 1986).

A distrofia ungueal provocada por Scytalidium dimidiatum ou por Scytalidium hyalinum é indistinguível da onicomicose por dermatófitos. Com experiência, é possível distinguir suas hifas, no exame direto, daquelas dos 
dermatófitos. Os filamentos de Scytalidium são frequentemente sinuosos com a aparência de duplo contorno e a largura é variável, dando um aspecto de pinçamento. Pode haver hifas pigmentadas, mas isso não é um achado constante (Moore, 1986; Elewski \& Greer, 1991).

É essencial que se faça a cultura em meio com e sem cicloheximida, se houver a suspeita de infecção por Scytalidium. Em um meio adequado, ambas as espécies de Scytalidium crescem rapidamente e ocupam toda a placa de Petri em 3 dias a uma temperatura de $26^{\circ} \mathrm{C}$. Scytalidium dimidiatum produz um micélio aéreo, fibroso, branca no inicio, tornando-se gradualmente cinza e depois negra. Os achados característicos na microscopia incluem hifas pigmentadas, septadas de várias larguras e cadeias de artroconídios. Scytalidium hyalinum apresenta colônia clara com hifas hialinas e artroconídios (Lacaz et al, 2002).

\subsubsection{Onicomicose por outros fungos filamentosos não dermatófitos}

Os FFND fazem parte de um grupo amplo e heterogêneo, que têm seu habitat em plantas e solos de todo o mundo. São considerados como fungos contaminantes, sapróbios e agentes oportunistas, porém nos últimos anos tem aumentado sua freqüência entre as micoses ungueais (Gianni et al, 2000).

Embora vários FFND já tenham sido isolados de unhas, somente algumas espécies são identificadas como agente de onicomicose. Estes incluem Scopulariopsis brevicaulis, Fusarium sp., Acremonium sp, Aspergillus sp., Scytalidium sp., Onichocola canadensis (English, 1968; Tosti 
et al, 2000). A prevalência e a ecologia da onicomicose por fungos filamentosos não dermatófitos varia de acordo com a região geográfica. Tosti et al (1999) na Itália, estabeleceram o diagnóstico de onicomicose em 431 dentre 1548 suspeitas de onicomicose e observaram 13,6\% ( $N=59)$ de fungos filamentosos não dermatófitos, dentre eles, $S$ brevicaulis, Fusarium $\mathrm{sp}$, Acremonium sp e Aspergillus sp. Gupta et al (2000), no Canadá diagnosticaram onicomicose por FFND em $7,7 \%$ dos casos.

A freqüência da onicomicose por FFND varia de 4,5 a $22 \%$ nos diferentes estudos (Srinivas et al, 1993; Tosti et al, 1999; Gianni et al, 2000; Gupta et al, 2000; Ghannoum et al, 2000; Araújo et al, 2003).

Uma das questões mais controversas no diagnóstico da onicomicose é como identificar uma infecção ungueal causada por um fungo filamentoso de comportamento geralmente saprófita. Geralmente os fungos saprófitas, diferentemente dos dermatófitos e de espécies de Scytalidium isoladas em regiões tropicais (Summerbell, 1997), não são considerados patogênicos toda vez que são isolados. Muitos destes fungos, na verdade, são mais comumente vistos como contaminantes de unhas do que como agentes etiológicos de tais infecções. No intuito de estabelecer um diagnóstico etiológico correto, são estabelecidos critérios diagnósticos para a infecção ungueal por fungos oportunistas, quais sejam a) a demonstração de formas invasivas de elementos fúngicos no exame micológico direto compatíveis com o fungo isolado b) e o isolamento do agente causal suspeito repetido sucessivamente em duas ou mais ocasiões separadas, na ausência de crescimento de dermatófito ou de Scytalidium sp (Gupta et al, 2001). 
Walshe e English (1966) recomendam que um fungo seja considerado agente causal sempre que a) no exame micológico direto haja elementos fúngicos e b) o fungo cresça em 5 ou mais dos 20 inóculos (isto é, porções do material ungueal implantado no meio de cultura) na ausência de um dermatófito. Este critério é baseado na premissa de que o fungo invasor irá colonizar uma proporção substancial do material ungueal, enquanto um contaminante terá um ou poucos propágulos dispersos. Este critério foi posteriormente restrito por English (1976) somente para os fungos saprófitas filamentosos, já que a contaminação por leveduras ocorre geralmente de forma disseminada no meio de cultura. Gupta et al (2001) demonstraram que o critério de contagem de colônias recomendado por Walshe e English leva a um resultado falso positivo de pelo menos $75 \%$ quando comparado ao critério da repetição da cultura. 
4. Métodos 


\subsection{Aspectos Éticos}

O presente estudo foi desenvolvido no ambulatório de Dermatologia do Hospital das Clínicas da Faculdade de Medicina da Universidade de São Paulo (HCFMUSP) e no Laboratório de Micologia do Instituto de Medicina Tropical (IMT) LIM-53 HCFMUSP, no período de dezembro de 2004 a novembro de 2005, após aprovação do Protocolo de Pesquisa n 775/04, pela Comissão de Ética para Análise de Projetos de Pesquisa - CAPPesq da Diretoria Clínica do Hospital das Clínicas e da Faculdade de Medicina da Universidade de São Paulo (Anexo A).

A aceitação dos doentes ou seus responsáveis foi documentada por meio de consentimento livre e esclarecido. Tal consentimento foi obtido após esclarecimento do estudo ao sujeito ou ao seu responsável, o qual foi feito pelo pesquisador executante, no ambulatório do Departamento de Dermatologia. O consentimento livre e esclarecido foi elaborado com base no modelo pré-estabelecido pela CAPPesq (Anexo B). 


\subsection{Casuística}

Foram estudados 205 pacientes, com suspeita clínica de onicomicose, tanto dos pododáctilos quanto dos quirodáctilos.

Foram incluídos no estudo os doentes com suspeita clínica de onicomicose encaminhados para o laboratório de micologia para coleta do exame micológico da unha. Eram considerados suspeitos de onicomicose aqueles doentes que apresentassem alteração da coloração, ou da espessura ou descolamento da lâmina ungueal A coleta foi realizada no período de dezembro de 2004 a novembro de 2005. O material ungueal foi coletado das unhas do(s) dedo(s) acometido(s) no laboratório de micologia do Departamento de Dermatologia do HC-FMUSP, após solicitação de médico do ambulatório de casos novos ou de retornos.

Foram excluídos do estudo os indivíduos que não aceitaram participar do mesmo ou aqueles cujos responsáveis não o permitiram. Não havia limite de idade, sexo ou etnia.

\subsection{Métodos}

Os doentes foram submetidos à anamnese e exame clínico dermatológico, que resultou no preenchimento de um protocolo para cada doente (Anexo C), ambos efetuados pelo pesquisador. 
A anamnese constou de: nome, sexo, idade, tempo de evolução da doença, comorbidades e uso de medicação antifúngica anterior ao estudo.

No exame dermatológico foi avaliado o número e identificadas as unhas acometidas, observados os seus aspectos e a coexistência ou não de tinea pedis elou tinea manuum.

A seguir, foi feita a coleta de amostra ungueal para exames micológicos (direto e cultura). A amostra da unha do doente com suspeita de onicomicose subungueal distal ou lateral foi obtida através do raspado subungueal, raspando a área infectada desde a porção distal até a proximal. Os primeiros detritos coletados da porção distal foram descartados, já que são ricos em contaminantes. As escamas obtidas da transição entre a unha normal e a afetada foram utilizadas para os exames micológicos. Na onicomicose proximal, a coleta foi transungueal, ou seja, a lâmina ungueal foi perfurada para que o acesso até o local da infecção fosse possível, e então realizado o raspado subungueal. A amostra da unha do paciente com suspeita de onicomicose superficial branca foi obtida por raspagem da parte superficial da lâmina ungueal, sobre a lesão branca. O instrumento utilizado para a coleta do material ungueal foi um esculpidor Lecron, flambado em bico de Bunsen imediatamente antes de cada coleta.

O exame micológico direto (MD) foi realizado após clarificação da amostra com uma solução de hidróxido de potássio $(\mathrm{KOH})$ a $10 \%$ e dimetilssulfóxido (DMSO) a 40\% no Microscópio Óptico Comum (MOC), com aumento de 10X. 
Para a cultura do fungo em potencial, a amostra foi semeada em meio de ágar Sabouraud com cloranfenicol com e sem cicloheximida, incubados por quatro semanas a temperatura ambiente ou a $25^{\circ} \mathrm{C}$. A identificação do agente foi realizada pela observação dos aspectos macroscópico (aspecto, consistência, tempo de desenvolvimento, pigmentação do verso e anverso dos cultivos) e micromorfológico da colônia (cultivo em lâmina examinado com o corante lactofenol azul de algodão) e, quando necessário, pelos testes fisiológicos e bioquímicos adequados a cada caso .

As provas fisiológicas utilizadas para a identificação dos fungos dermatófitos foram: teste da pigmentação em Ágar Batata, prova da urease e cultivo em meio arroz autoclavado. As provas bioquímicas para a identificação das leveduras foram: cultivo em lâmina em ágar fubá, auxanograma e zimograma.

O diagnóstico de onicomicose causada por fungos filamentosos não dermatófitos (FFND) foi estabelecido com base nos seguintes critérios: (1) alteração ungueal clinicamente consistente com a hipótese diagnóstica; (2) exame micológico direto com a presença de filamentos fúngicos; (3) ausência de crescimento de fungos dermatófitos; (4) crescimento do mesmo FFND em duas coletas repetidas em datas diferentes. O intervalo entre a primeira coleta e a repetição desta foi de pelo menos uma semana. 


\subsubsection{Meios e Técnicas Empregados}

Ágar Sabouraud com cloranfenicol e cicloheximida, ágar batata ou ágar fubá, meios para assimilação de fontes de carbono e de nitrogênio para fermentação de carboidratos e para a prova da uréase foram utilizados (Lacaz et al, 2002).

\subsubsection{Técnica para identificação dos dermatófitos e outros fungos filamentosos}

\section{Cultivo em lâminas}

Para estudar as estruturas vegetativas e de reprodução foi empregada a técnica de cultivo em lâmina (Porto et al,1981). Resumidamente:

a) fundir o meio de ágar batata estéril, colocar em placa de Petri estéril, em camada fina, deixar solidificar;

b) esterilizar uma placa de Petri, preparada com duas lâminas de vidro dispostas em cruz, uma sobre a outra;

c) cortar um pequeno quadrado do ágar batata e colocar sobre a lâmina;

d) semear o cultivo, em estudo, nas quatro laterais do quadrado de ágar batata com o auxílio da alça de platina;

e) dispor uma lamínula limpa, previamente flambada, sobre o meio;

f) colocar um algodão embebido em água destilada estéril na periferia da placa ;

g) lacrar a placa com fita adesiva; 
h) incubar a $25^{\circ} \mathrm{C}$ até haver conidiação;

i) retirar a lamínula, colocar sobre uma lâmina com corante lactofenol azul de algodão, vedar com esmalte incolor;

j) examinar ao microscópio ótico comum, com aumento de 40X.

\section{Diferenciação de T. rubrum e T. mentagrophytes}

\section{Prova de urease:}

\section{Técnica:}

a - Cultivar o dermatófito no meio de Christensen (1946).

b - fazer observações diárias até $010^{\circ}$ dia de incubação à temperatura de $25^{\circ} \mathrm{C}$.

A maior parte das espécies de T. mentagrophytes muda o $\mathrm{pH}$ do meio tornando-o vermelho em 3 a 5 dias. T. rubrum não altera a cor do meio, só o fazendo tardiamente, após o $8^{\circ}$ dia.

\subsubsection{Técnicas para a identificação das leveduras}

Cultura em meio de ágar-fubá (Lacaz et al, 2002)

a - colocar sobre uma lâmina disposta sobre um bastão de vidro em forma de $U$, em placa de Petri estéreis, uma camada de meio previamente liquefeito em banho-Maria;

b - após solidificação, semear em 3 estrias a levedura em estudo, cortando levemente o meio;

c - cobrir a preparação com lamínula limpa, previamente flambada; 
d - adicionar água destilada estéril no fundo da placa;

e - incubar a $25^{\circ} \mathrm{C}$;

f - após 24 horas examinar ao microscópio a lâmina montada e verificar a formação das estruturas como hifas, pseudo-hifas, artroconídios, blastoconídios e clamidoconídios. A presença de clamidósporo é característica de C. albicans.

\subsection{Análise Estatística}

A análise estatística descritiva foi utilizada para a caracterização da amostra de doentes.

A comparação entre eventos frequenciais foi feita utilizando-se o teste do $x^{2}$ (qui-quadrado), bicaudal, com 95\% de confiança.

Tanto o teste $\mathrm{x}^{2}$ (qui-quadrado), quanto o teste Exato de Fisher foram utilizados para verificar a associação de variáveis de interesse a priori definidas, tais como cultura, MD, FFND ou leveduras. Foi adotado o nível de 5\% de significância. 
5. Resultados 


\subsection{Caracterização da população geral}

Dentre os 205 doentes estudados, observou-se que a idade mínima foi de 5 anos e a idade máxima 89 anos. A idade média foi de 48 anos, com um desvio padrão de 17,23, observando-se um coeficiente de variação maior que 0,3 concluindo-se que a medida mais representativa da idade dessa população seria a mediana, 49 anos de idade (Tab. 1). Com relação à distribuição por sexo (Fig. 1) 67\% eram do sexo feminino e $33 \%$ do sexo masculino (aproximadamente 2:1).

O total de doentes ou exames em cada tabela ou figura pode variar de acordo com a possibilidade de coleta do dado no momento do estudo. 
Tabela 1 - Distribuição dos doentes com suspeita clínica de Onicomicose atendidos no ambulatório de Dermatologia do Hospital das Clinicas da Faculdade de Medicina da Universidade de São Paulo, no período de dezembro de 2004 a novembro de 2005, quanto à faixa etária

\begin{tabular}{lll}
\hline Idade & $\mathbf{N}$ & $\%$ \\
\hline $0-19$ & 14 & 6,8 \\
$20-29$ & 17 & 8,3 \\
$30-39$ & 35 & 17,1 \\
$40-49$ & 37 & 18,0 \\
$50-59$ & 46 & 22,4 \\
$60-69$ & 39 & 19,0 \\
70 ou + & 17 & 8,4 \\
\hline Total & $\mathbf{2 0 5}$ & $\mathbf{1 0 0 , 0}$
\end{tabular}

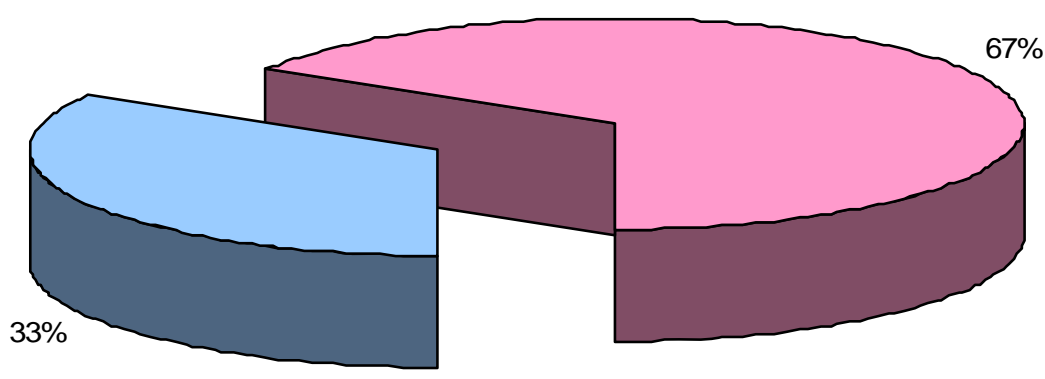

$\square$ Masculino $\square$ Feminino

Figura 1 - Distribuição dos doentes com suspeita clínica de Onicomicose atendidos no ambulatório de Dermatologia do Hospital das Clinicas da Faculdade de Medicina da Universidade de São Paulo, no período de dezembro de 2004 a novembro de 2005 , quanto ao sexo 
Observa-se que a maioria dos doentes $(76,5 \%)$ encontra-se na faixa etária de 30 a 69 anos de idade, faixa de população economicamente ativa.

Quanto ao tempo de evolução (Fig. 2), aproximadamente 61\% dos doentes apresentavam doença ungueal há menos de 5 anos.

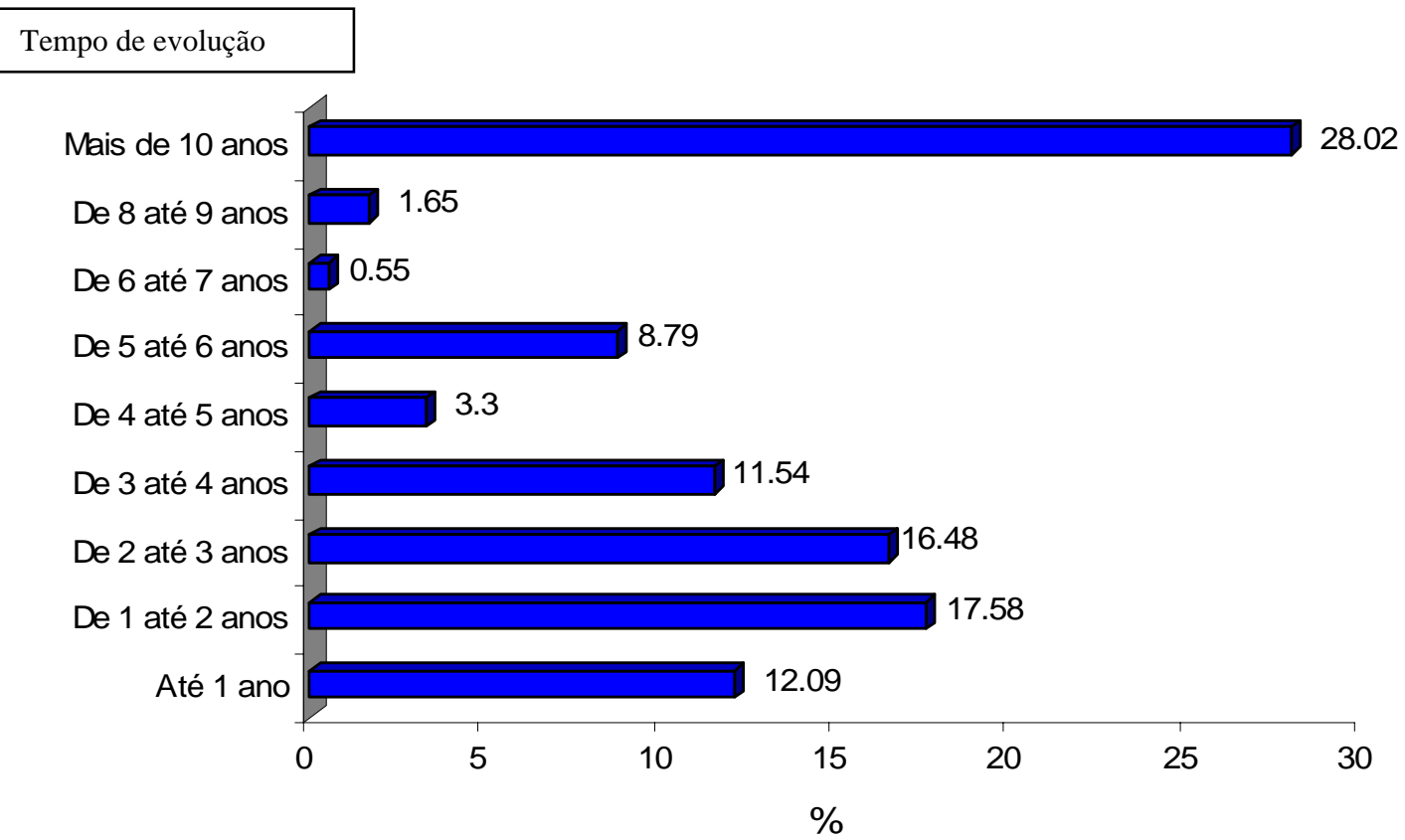

Figura 2 - Distribuição dos doentes com suspeita clínica de Onicomicose atendidos no ambulatório de Dermatologia do Hospital das Clinicas da Faculdade de Medicina da Universidade de São Paulo, no período de dezembro de 2004 a novembro de 2005, quanto ao tempo de evolução da doença

Observou-se a presença de secreção purulenta na unha afetada em $1,48 \%$ dos doentes.

Quanto ao hábito de lidar com plantas, apenas 3,45\% dos doentes o referiam. 
Cerca de $14,29 \%$ dos doentes queixavam-se de dor na unha comprometida.

Referiam tratamento da onicomicose anteriormente a este estudo $30,05 \%$ dos doentes.

Quanto às comorbidades (Tab. 2), 11\% dos doentes apresentavam o diagnóstico de DM (Diabetes Mellitus) e aproximadamente 2\% deles imunodepressão.

Tabela 2 - Distribuição dos doentes com suspeita clínica de Onicomicose atendidos no ambulatório de Dermatologia do Hospital das Clinicas da Faculdade de Medicina da Universidade de São Paulo, no período de dezembro de 2004 a novembro de 2005, quanto à presença de comorbidades

\begin{tabular}{lcc}
\hline Comorbidades & $\mathbf{N}$ & $\%$ \\
\hline Diabetes Mellitus & 23 & 11,33 \\
Imunodepressão & 4 & 1,98 \\
Nenhuma & 176 & 86,7 \\
\hline Total & $\mathbf{2 0 3}$ & $\mathbf{1 0 0}$ \\
\hline
\end{tabular}

A unha do primeiro pododáctilo é a mais acometida (Tab. 3), em aproximadamente $95,70 \%$ dos casos esta unha esteve envolvida, quer isoladamente ou concomitantemente com unhas de outros pododáctilos. Não houve acometimento da unha do primeiro pododáctilo somente em 4,30\% dos casos. 
Tabela 3 - Distribuição dos doentes com suspeita clínica de Onicomicose atendidos no ambulatório de Dermatologia do Hospital das Clinicas da Faculdade de Medicina da Universidade de São Paulo, no período de dezembro de 2004 a novembro de 2005, quanto às unhas dos pés acometidas

\begin{tabular}{llll}
\hline Unhas acometidas & N & $\%$ \\
\hline Primeiro pododáctilo apenas & 106 & 57,00 & \\
Primeiro pododáctilo e outros & & 72 & 38,7 \\
Outros pododáctilos & 8 & & 4,3 \\
\hline Total & & $\mathbf{1 8 6}$ & $\mathbf{1 0 0}$ \\
\hline
\end{tabular}

Quanto aos indivíduos com suspeita clinica de onicomicose com acometimento das unhas dos quirodáctilos (Tab. 4) a maioria deles apresentava acometimento da unha do primeiro quirodáctilo, associado ou não ao acometimento de outros quirodáctilos $(89,70 \%)$.

Tabela 4 - Distribuição dos doentes com suspeita clínica de Onicomicose atendidos no ambulatório de Dermatologia do Hospital das Clinicas da Faculdade de Medicina da Universidade de São Paulo, no período de dezembro de 2004 a novembro de 2005, quanto às unhas das mãos acometidas

\begin{tabular}{lcc}
\hline Unhas acometidas & $\mathbf{N}$ & $\%$ \\
\hline Primeiro quirodáctilo apenas & 10 & 34,5 \\
Primeiro e outros quirodáctilos & 16 & 55,2 \\
Outros quirodáctilos & 3 & 10,3 \\
\hline Total & $\mathbf{2 9}$ & $\mathbf{1 0 0}$ \\
\hline
\end{tabular}


A maioria dos indivíduos com suspeita de onicomicose apresentava tinea pedis associada (59\%), comprovada por exame micológico direto,(Tab. 5).

Tabela 5 - Distribuição dos doentes com suspeita clínica de Onicomicose atendidos no ambulatório de Dermatologia do Hospital das Clinicas da Faculdade de Medicina da Universidade de São Paulo, no período de dezembro de 2004 a novembro de 2005, quanto à associação com tinea pedis e/ou tinea manuum

\begin{tabular}{lll}
\hline Tinea & $\mathbf{N}$ & $\%$ \\
\hline Tinea pedis & 115 & 56,65 \\
Tinea manuum & 1 & 0,49 \\
Tinea pedis e Tinea manuum & 4 & 1,97 \\
Nenhum & 83 & 40,89 \\
\hline Total & $\mathbf{2 0 3}$ & $\mathbf{1 0 0}$ \\
\hline
\end{tabular}

Cerca de 95\% dos doentes apresentavam alteração da espessura ungueal ou onicólise e apenas 4,93\% dos doentes apresentavam qualquer alteração da cor da unha acometida.

O exame micológico direto foi positivo em 84\% das vezes (Fig. 3). 


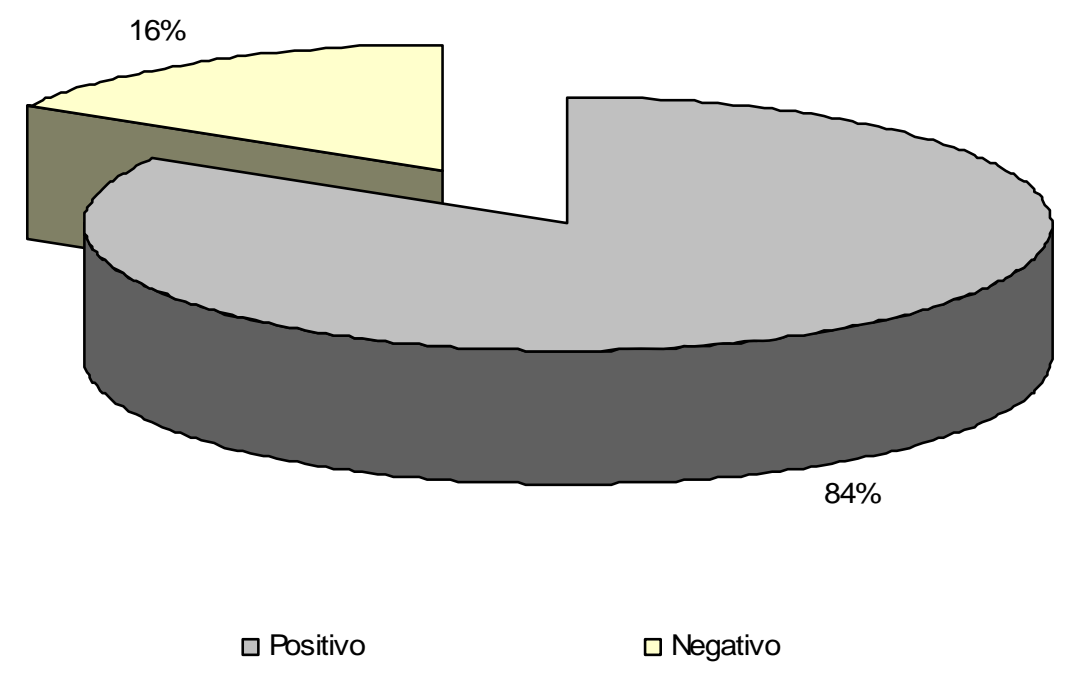

Figura 3 - Distribuição dos doentes com suspeita clínica de Onicomicose atendidos no ambulatório de Dermatologia do Hospital das Clinicas da Faculdade de Medicina da Universidade de São Paulo, no período de dezembro de 2004 a novembro de 2005, quanto ao resultado do exame micológico direto

Dentre os 205 indivíduos clinicamente suspeitos de onicomicose, houve a confirmação laboratorial por exame micológico direto em 170 pessoas ou 171 vezes, porque um dos estudados apresentou no exame micológico direto de unha do quirodáctilo, pseudo-hifas e blastoconídios, e no exame micológico da unha do pododáctilo, hifas hialinas septadas (Tab. 6).

Ressalta-se que 170 suspeitos revelaram a presença de elementos fúngicos no exame microscópico direto, 1 apresentou tal resultado nas unhas das mãos e dos pés e 1 apresentou exame microscópico direto negativo com cultivo positivo. 
Tabela 6 - Relação dos exames microscópicos direto versus cultivos nos doentes com suspeita clínica de Onicomicose atendidos no ambulatório de Dermatologia do Hospital das Clinicas da Faculdade de Medicina da Universidade de São Paulo, no período de dezembro de 2004 a novembro de 2005

\begin{tabular}{lllllll}
\hline \multirow{2}{*}{ Cultura para } & \multicolumn{6}{c}{ Exame Microscópico Direto } \\
\cline { 2 - 7 } & \multicolumn{2}{c}{ Positivo } & \multicolumn{2}{c}{ Negativo } & \multicolumn{2}{c}{ Total } \\
\cline { 2 - 7 } & $\mathbf{N}$ & $\%$ & N & $\%$ & N & $\%$ \\
\hline Positivo & 106 & 51,71 & 1 & 0,49 & 107 & 52,20 \\
Negativo & 65 & 31,70 & 33 & 16,10 & 98 & 47,80 \\
\hline Total & $\mathbf{1 7 1}$ & $\mathbf{8 3 , 4 1}$ & $\mathbf{3 4}$ & $\mathbf{1 6 , 5 9}$ & $\mathbf{2 0 5}$ & $\mathbf{1 0 0 , 0 0}$ \\
\hline
\end{tabular}

Os principais fungos isolados no cultivo foram os dermatófitos, seguidos pelas candidas e FFND em porcentagens muito próximas (Tab. 7).

Houve 28 casos com cultura positiva para Candida sp, sem correlação com exame micológico direto, que não foram considerados casos, sendo que em 14 destes houve o isolamento de dermatófito. Todos estes 28 casos foram considerados como contaminação. 
Tabela 7 - Distribuição das culturas positivas coletadas dos doentes com suspeita clínica de Onicomicose atendidos no ambulatório de Dermatologia do Hospital das Clinicas da Faculdade de Medicina da Universidade de São Paulo, no período de dezembro de 2004 a novembro de 2005

Fungos

Freqüências

$\mathrm{N} \quad \%$

Dermatófitos

Trichophyton rubrum

68

63,56

Trichophyton tonsurans

08

7,48

Trichophyton mentagrophytes

08

7,48

Subtotal

84

78,52

Leveduras

Candida albicans

07

6,54

Candida sp

07

6,54

Subtotal

14

13,08

FFND

Scytalidium dimidiatum

06

5,62

Fusarium solani

02

1,87

Aspergillus sp

01

0,91

Subtotal

09

8,40

Total

107

100,00

Nota: FFND = fungos filamentosos não dermatófitos 


\subsection{Caracterização dos doentes que apresentaram exame micológico direto positivo}

Dentre os 170 doentes que apresentaram exame micológico direto positivo, a mediana de idade foi de 49 anos (Quadro)., sendo 64\% do sexo feminino (Tab. 8).

Quadro - Distribuição quanto à idade dos doentes com exame micológico direto positivo, atendidos no ambulatório de Dermatologia do Hospital das Clinicas da Faculdade de Medicina da Universidade de São Paulo, no período de dezembro de 2004 a novembro de 2005

\begin{tabular}{|l|c|}
\hline \multicolumn{1}{|c|}{ Medidas Descritivas } & Idade (anos) \\
\hline Média & 46,42 \\
\hline Mediana & 49,00 \\
\hline Moda & 39,00 \\
\hline Desvio padrão & 17,65 \\
\hline Mínimo & 5,00 \\
\hline Máximo & 89,00 \\
\hline Coeficiente de Variação & 0,38 \\
\hline
\end{tabular}


Tabela 8 - Distribuição quanto ao gênero dos doentes com exame micológico direto positivo, atendidos no ambulatório de Dermatologia do Hospital das Clinicas da Faculdade de Medicina da Universidade de São Paulo, no período de dezembro de 2004 a novembro de 2005

\begin{tabular}{lccccccc}
\hline & & \multicolumn{2}{c}{ Positivo } & \multicolumn{2}{c}{ Negativo } & \multicolumn{2}{c}{ Total } \\
\cline { 2 - 8 } & Sexo & $\mathbf{N}$ & $\%$ & $\mathbf{N}$ & $\%$ & $\mathbf{N}$ & $\%$ \\
\hline Masculino & 61 & 35,88 & 7 & 21,21 & 68 & 89,70 \\
Feminino & 109 & 64,12 & 26 & 78,79 & 135 & 80,74 \\
\hline Total & 170 & $\mathbf{1 0 0}$ & $\mathbf{3 3}$ & $\mathbf{1 0 0}$ & $\mathbf{3 3}$ & - \\
\hline
\end{tabular}

Nota: Qui-quadrado $p=0,1023$

O teste estatístico do qui-quadrado, feito para comparação dos gêneros, na população estudada, mostrou que não há diferença $(p=0,1023)$ entre a porcentagem de positividade do exame microscópico direto entre os dois sexos, no nível de significância adotado (Tab. 8). 
Tabela 9 - Distribuição quanto ao tempo de evolução da doença nos doentes com exame micológico direto positivo, atendidos no ambulatório de Dermatologia do Hospital das Clinicas da Faculdade de Medicina da Universidade de São Paulo, no período de dezembro de 2004 a novembro de 2005

\begin{tabular}{lcccc}
\hline & \multicolumn{2}{c}{ Positivo } & \multicolumn{2}{c}{ Negativo } \\
\cline { 2 - 5 } Tempo de evolução & $\mathbf{N}$ & $\%$ & $\mathbf{N}$ & $\%$ \\
\hline Até 1 ano & 16 & 10.39 & 6 & 21.43 \\
De 1 até 2 anos & 25 & 16.23 & 7 & 25 \\
De 2 até 3 anos & 27 & 17.53 & 3 & 10.71 \\
De 3 até 4 anos & 18 & 11.69 & 3 & 10.71 \\
De 4 até 5 anos & 6 & 3.9 & - & - \\
De 5 até 6 anos & 13 & 8.44 & 3 & 10.71 \\
De 6 até 7 anos & 1 & 0.65 & - & - \\
De 8 até 9 anos & 3 & 1.95 & - & - \\
Mais de 10 anos & 154 & 100 & $\mathbf{2 8}$ & 100 \\
\hline Total & & & 6 & 21.43 \\
\hline
\end{tabular}

Quanto ao tempo de evolução de doença (Tab. 9), aproximadamente a metade apresentavam doença ungueal há 4 anos ou menos.

A maioria dos doentes $(70,59 \%)$ com exame micológico positivo referiu não ter feito qualquer tratamento anterior para onicomicose (Tab. 9), assim como a maioria $(66,67 \%)$ dos doentes com exame micológico direto negativo $(p=0,6530)$. 
Tabela 10 - Distribuição quanto à presença de comorbidades nos doentes com exame micológico direto positivo, atendidos no ambulatório de Dermatologia do Hospital das Clinicas da Faculdade de Medicina da Universidade de São Paulo, no período de dezembro de 2004 a novembro de 2005.

\begin{tabular}{|c|c|c|}
\hline \multirow[b]{2}{*}{ Comorbidades } & \multicolumn{2}{|c|}{ Positivo } \\
\hline & $\mathbf{n}$ & $\%$ \\
\hline DM & 18 & 10,59 \\
\hline Imunodepressão & 3 & 1,76 \\
\hline Nenhum & 149 & 87,65 \\
\hline Total & 170 & 100 \\
\hline
\end{tabular}

Nota: Teste Exato de Fisher $p=0,3851$

Nota-se (Tab. 10) que a maioria dos doentes com exame microscópico positivo não apresentou nenhum tipo de comorbidade $(87,65 \%)$. Estas variáveis não apresentam associação $(p=0,3851)$. 
Tabela 11 - Distribuição quanto ao tipo clínico de onicomicose nos doentes com exame micológico direto positivo, atendidos no ambulatório de Dermatologia do Hospital das Clinicas da Faculdade de Medicina da Universidade de São Paulo, no período de dezembro de 2004 a novembro de 2005

\begin{tabular}{lcc}
\hline Tipo Clínico & N & \% \\
\hline Subungueal Distal e ou lateral & 145 & 85,3 \\
Subungueal Proximal & 6 & 3,5 \\
Acometimento Total * & 13 & 7,6 \\
Superficial & 6 & 3,5 \\
\hline Total & $\mathbf{1 7 0}$ & $\mathbf{1 0 0}$ \\
\hline
\end{tabular}

* o acometimento ungueal total incluía toda a unha, não sendo possível a classificação entre os tipos clínicos

A maioria dos doentes (85,3\%) apresenta onicomicose do tipo subungueal distal e/ou lateral (Tab. 11). 
Tabela 12 - Distribuição quanto às unhas dos pés acometidas nos doentes com exame micológico direto positivo, atendidos no ambulatório de Dermatologia do Hospital das Clinicas da Faculdade de Medicina da Universidade de São Paulo, no período de dezembro de 2004 a novembro de 2005

Unhas dos pés acometidas

$\mathrm{N} \quad \%$

Primeiro pododáctilo apenas

84

53,8

Primeiro pododáctilo e outros

65

41,7

Outros pododáctilos

7

4,5

Total

156

100

Nota-se que a unha do primeiro pododáctilo é a mais acometida, em $95,5 \%$ dos casos esta unha esteve envolvida, quer isoladamente ou concomitantemente com unhas de outros pododáctilos (Tab. 12). 
Tabela 13 - Distribuição quanto às unhas acometidas das mãos nos doentes com exame micológico direto positivo, atendidos no ambulatório de Dermatologia do Hospital das Clinicas da Faculdade de Medicina da Universidade de São Paulo, no período de dezembro de 2004 a novembro de 2005

\begin{tabular}{lcc}
\hline Unhas das mãos acometidas & N & $\%$ \\
\hline Primeiro quirodáctilo apenas & 9 & 36 \\
Primeiro e outros quirodáctilos & 13 & 52 \\
Outros quirodáctilos & 3 & 12 \\
\hline Total & $\mathbf{2 5}$ & $\mathbf{1 0 0}$ \\
\hline
\end{tabular}

Quanto aos indivíduos com exame micológico direto positivo com relação ao acometimento das unhas dos quirodáctilos (Tab. 13), a maioria também apresentava acometimento da unha do primeiro quirodáctilo (88\%). 
Tabela 14 - Distribuição quanto à presença de tinea pedis e/ou tinea manuum nos doentes com exame micológico direto positivo, atendidos no ambulatório de Dermatologia do Hospital das Clinicas da Faculdade de Medicina da Universidade de São Paulo, no período de dezembro de 2004 a novembro de 2005

\begin{tabular}{lll}
\hline Tinea & N & \% \\
\hline Tinea pedis & 112 & 65,88 \\
Tinea manuum & 1 & 0,59 \\
Tinea pedis e Tinea manuum & 4 & 2,35 \\
Nenhuma & 53 & 31,18 \\
\hline Total & $\mathbf{1 7 0}$ & $\mathbf{1 0 0}$ \\
\hline
\end{tabular}

Nota: Teste Exato de Fisher $p<0,0001$

Nota-se que a maioria dos indivíduos com exame micológico direto positivo de unha (Tab. 14) apresentou tinea pedis associada $(65,9 \%)$. Pelo teste Exato de Fisher a associação foi significativa ( $p<0,0001)$. 
Tabela 15 - Distribuição quanto à positividade da cultura para fungos nos doentes com exame micológico direto positivo, atendidos no ambulatório de Dermatologia do Hospital das Clinicas da Faculdade de Medicina da Universidade de São Paulo, no período de dezembro de 2004 a novembro de 2005

\begin{tabular}{lccc}
\hline & Cultura & N & $\%$ \\
\hline Positivo & & 105 & 61,76 \\
Negativo & & 65 & 38,24 \\
\hline & Total & $\mathbf{1 7 0}$ & 100 \\
\hline
\end{tabular}

Nota: Qui-quadrado $p<0,0001$

Há associação positiva (Tab. 15) entre as variáveis cultura e exame micológico direto positivo ( $p<0,0001)$.

A associação mais freqüente (Tab. 16) foi onicomicose distal dos pés causada pelo T. rubrum, aparecendo em 61 resultados. 
Tabela 16 - Distribuição quanto ao agente infeccioso por localização de acometimento ungueal e tipo clinico de onicomicose nos doentes com exame micológico direto positivo, atendidos no ambulatório de Dermatologia do Hospital das Clinicas da Faculdade de Medicina da Universidade de São Paulo, no período de dezembro de 2004 a novembro de 2005

\begin{tabular}{|c|c|c|c|c|c|c|c|c|c|c|c|c|}
\hline \multirow{2}{*}{ Cultura } & \multicolumn{3}{|c|}{ Distal } & \multicolumn{3}{|c|}{ Proximal } & \multicolumn{3}{|c|}{ Superficial Branca } & \multicolumn{3}{|c|}{ Acometimento Total } \\
\hline & Ambos & Mãos & Pés & Ambos & Mãos & Pés & Ambos & Mãos & Pés & Ambos & Mãos & Pés \\
\hline C. albicans & 1 & 4 & - & - & 2 & - & - & - & - & - & - & - \\
\hline Candida sp & - & 5 & 1 & - & - & - & - & - & 1 & - & - & - \\
\hline Fusarium & - & - & 1 & - & - & - & - & - & - & - & - & 1 \\
\hline Scytalidium & 2 & - & 4 & - & - & - & - & - & - & - & - & - \\
\hline Aspergillus & - & - & 1 & - & - & - & - & - & - & - & - & - \\
\hline T. mentagrophytes & - & - & 5 & - & - & - & - & - & 3 & - & - & - \\
\hline T. rubrum & 5 & 1 & 61 & - & - & - & - & - & - & - & - & 1 \\
\hline T. tonsurans & - & - & 8 & - & - & - & - & - & - & - & - & - \\
\hline $\mathrm{MD}+$ & - & 4 & 47 & - & - & 1 & - & 1 & 1 & 1 & - & 10 \\
\hline Total & 9 & 14 & 153 & - & 2 & 1 & 1 & - & 5 & 1 & - & 15 \\
\hline
\end{tabular}

Nota: MD+= exame micológico direto positivo 


\subsection{Caracterização dos doentes que apresentaram exame micológico direto positivo de unha e cultura para fungos negativa}

Dentre os 170 doentes que apresentaram exame micológico direto positivo, não foi identificado o agente etiológico pela cultura para fungo em 65 deles (38,2\%). Dentre estes, a maioria é do sexo feminino (64,6\%). A idade mínima foi de 5 anos, a máxima 89 anos, a idade media foi de 51,8 anos e a mediana foi de 53 anos.

Tabela 17 - Distribuição quanto ao tempo de evolução da doença nos doentes com exame micológico direto positivo e cultivo para fungos negativo, atendidos no ambulatório de Dermatologia do Hospital das Clinicas da Faculdade de Medicina da Universidade de São Paulo, no período de dezembro de 2004 a novembro de 2005

\begin{tabular}{lcccc}
\hline Tempo de evolução da doença & N & $\%$ & fa & $\%$ \\
\hline Até 1 ano & 7 & 11,48 & 7 & 11,48 \\
De 1 até 2 & 8 & 13,11 & 15 & 24,59 \\
De 2 até 3 & 12 & 19,67 & 27 & 44,26 \\
De 3 até 4 & 7 & 11,48 & 34 & 55,74 \\
De 4 até 5 & 2 & 3,28 & 36 & 59,02 \\
De 5 até 6 & 6 & 9,84 & 42 & 68,85 \\
De 6 até 7 & 1 & 1,64 & 43 & 70,49 \\
De 8 até 9 & 1 & 1,64 & 44 & 72,13 \\
Mais de 10 & 17 & 27,87 & 61 & 100,00 \\
\hline
\end{tabular}

Nota: fa = freqüência acumulada

A maioria dos doentes (55,74\%) apresenta a doença há 4 anos ou menos (Tab. 17). 
Tabela 18 - Distribuição quanto à realização de tratamento anterior para onicomicose nos doentes com exame micológico direto positivo e cultivo para fungos negativo, atendidos no ambulatório de Dermatologia do Hospital das Clinicas da Faculdade de Medicina da Universidade de São Paulo, no período de dezembro de 2004 a novembro de 2005

\begin{tabular}{lcc}
\hline Tratamentos atuais ou anteriores & N & $\%$ \\
\hline Não & 51 & 78,46 \\
Sim & 14 & 21,54 \\
\hline Total & 65 & 100,00 \\
\hline
\end{tabular}

A minoria dos doentes com exame microscópico direto positivo e cultivo para fungos negativo $(21,54 \%)$ referiu ter feito algum tratamento anterior para onicomicose (Tab. 18).

Tabela 19 - Distribuição quanto à presença de comorbidades nos doentes com exame micológico direto positivo e cultivo para fungos negativo, atendidos no ambulatório de Dermatologia do Hospital das Clinicas da Faculdade de Medicina da Universidade de São Paulo, no período de dezembro de 2004 a novembro de 2005

\begin{tabular}{lcc}
\hline Comorbidades & N & $\%$ \\
\hline DM & 14 & 21,50 \\
Imunodepressão & 1 & 1,50 \\
Nenhuma & 50 & 77,00 \\
\hline Total & 65 & $\mathbf{1 0 0 , 0 0}$ \\
\hline
\end{tabular}

Prevaleceu a ausência de co-morbidades (77,00\%) nesta amostra (Tab. 19). 
Tabela 20 - Distribuição quanto às unhas dos pododáctilos acometidas nos doentes com exame micológico direto positivo e cultivo para fungos negativo, atendidos no ambulatório de Dermatologia do Hospital das Clinicas da Faculdade de Medicina da Universidade de São Paulo, no período de dezembro de 2004 a novembro de 2005

\begin{tabular}{lcc}
\hline Pododáctilo acometido & N & $\%$ \\
\hline Primeiro apenas & 31 & 47,69 \\
Primeiro e outros & 27 & 41,54 \\
Outros & 2 & 3,08 \\
Nenhum & 5 & 7,69 \\
\hline Total & $\mathbf{6 5}$ & $\mathbf{1 0 0 , 0 0}$ \\
\hline
\end{tabular}

A maioria dos doentes com exame micológico direto positivo e cultivo para fungos negativo (Tab. 20), apresentou o primeiro pododáctilo comprometido $(89,23 \%)$ enquanto que o total dos quirodáctilos (Tab. 21) apresentou freqüência bem menor (9,2\%). A tinha dos pés $(66,15 \%)$ acompanhou a onicomicose com maior freqüência (Tab. 22) que a tinha da mão $(1,54)$. 
Tabela 21 - Distribuição quanto às unhas dos quirodáctilos acometidas nos doentes com exame micológico direto positivo e cultivo para fungos negativo, atendidos no ambulatório de Dermatologia do Hospital das Clinicas da Faculdade de Medicina da Universidade de São Paulo, no período de dezembro de 2004 a novembro de 2005

\begin{tabular}{lcc}
\hline Quirodáctilo acometido & N & $\%$ \\
\hline Primeiro & 1 & 1,5 \\
Primeiro e outros & 3 & 4,6 \\
Outros & 2 & 3,1 \\
Nenhum & 59 & 90,8 \\
\hline Total & 65 & $\mathbf{1 0 0 , 0 0}$ \\
\hline
\end{tabular}

Tabela 22 - Distribuição quanto à presença de tinea pedis e/ou tinea manuum nos doentes com exame micológico direto positivo e cultivo para fungos negativo, atendidos no ambulatório de Dermatologia do Hospital das Clinicas da Faculdade de Medicina da Universidade de São Paulo, no período de dezembro de 2004 a novembro de 2005

\begin{tabular}{lcc}
\hline Tinea & N & $\%$ \\
\hline Pedis & 43 & 66,15 \\
Manuum & 1 & 1,54 \\
Nenhum & 21 & 32,31 \\
\hline Total & $\mathbf{6 5}$ & $\mathbf{1 0 0 , 0 0}$ \\
\hline
\end{tabular}




\subsection{Caracterização dos doentes que apresentaram cultura para fungo positiva, independente do resultado do exame micológico direto}

Dentre os 106 doentes que apresentaram cultura positiva 35,85\% são do sexo masculino e $64,15 \%$ do sexo feminino. A idade mínima foi de 6 anos, a máxima 80 anos, a idade média e a mediana foram de 43,5 anos.

Tabela 23 - Distribuição quanto ao gênero nos doentes com cultivo para fungos positivo, atendidos no ambulatório de Dermatologia do Hospital das Clinicas da Faculdade de Medicina da Universidade de São Paulo, no período de dezembro de 2004 a novembro de 2005

\begin{tabular}{lccc}
\hline Sexo & N & $\%$ \\
\hline Masculino & 38 & 35,85 \\
Feminino & 68 & 64,15 \\
\hline & Total & $\mathbf{1 0 6}$ & $\mathbf{1 0 0 , 0 0}$ \\
\hline
\end{tabular}

Nota: Qui-quadrado, $p=0,4581$

Não se observou associação (Tab. 23) entre as variáveis sexo e cultura para fungos positiva ( $p=0,4581)$. 
Tabela 24 - Distribuição quanto ao tempo de evolução de doença nos doentes com cultivo para fungos positivo, atendidos no ambulatório de Dermatologia do Hospital das Clinicas da Faculdade de Medicina da Universidade de São Paulo, no período de dezembro de 2004 a novembro de 2005

\begin{tabular}{lcc}
\hline Tempo de evolução & \multicolumn{2}{c}{ Cultura positiva } \\
\cline { 2 - 3 } & $\mathbf{N}$ & $\%$ \\
\hline Até 1 ano & 9 & 9,57 \\
De 1 até 2 anos & 17 & 18,09 \\
De 2 até 3 anos & 15 & 15,96 \\
De 3 até 4 anos & 13 & 13,83 \\
De 4 até 5 anos & 2 & 2,13 \\
De 5 até 6 anos & 7 & 7,45 \\
De 6 até 7 anos & - & - \\
De 8 até 9 anos & 2 & 2,13 \\
Mais de 10 anos & 29 & 30,85 \\
\hline Total & 94 & 100 \\
\hline
\end{tabular}

Nota: Teste Exato de Fisher, $p=0,9217$

A maioria dos doentes apresentava onicomicose há 4 anos ou menos (Tab24).

Pode-se dizer com 95\% de confiança que não existe associação entre as variáveis tempo de evolução e a cultura para fungos positiva (Tab. 24). 
Tabela 25 - Distribuição quanto à presença de comorbidades nos doentes com cultivo para fungos positivo, atendidos no ambulatório de Dermatologia do Hospital das Clinicas da Faculdade de Medicina da Universidade de São Paulo, no período de dezembro de 2004 a novembro de 2005

\begin{tabular}{|c|c|c|}
\hline \multirow[t]{2}{*}{ Comorbidades } & \multicolumn{2}{|c|}{ Positivo } \\
\hline & $\mathbf{N}$ & $\%$ \\
\hline DM & 4 & 3,77 \\
\hline Imunodepressão & 2 & 1,89 \\
\hline Nenhum & 100 & 94,34 \\
\hline Total & 106 & 100,00 \\
\hline
\end{tabular}

Também neste grupo a associação com co-morbidades (Tab. 25) foi espúria. Quanto ao acometimento das unhas dos pés (Tab. 26), a unha do hálux foi envolvida em mais de $90 \%$ das vezes.

Tabela 26 - Distribuição quanto às unhas dos pés acometidas nos doentes com cultivo para fungos positivo, atendidos no ambulatório de Dermatologia do Hospital das Clinicas da Faculdade de Medicina da Universidade de São Paulo, no período de dezembro de 2004 a novembro de 2005

\begin{tabular}{lcc}
\hline Unhas dos pés acometidas & $\mathbf{N}$ & $\%$ \\
\hline Primeiro & 53 & 58,49 \\
Primeiro e outros & 39 & 36,79 \\
Outros & 5 & 4,72 \\
\hline Total & $\mathbf{9 7}$ & $\mathbf{1 0 0}$ \\
\hline
\end{tabular}

Nota: Teste Exato de Fisher, $p=0,8975$ 
Tabela 27 - Distribuição quanto às unhas acometidas das mãos nos doentes com cultivo para fungos positivo, atendidos no ambulatório de Dermatologia do Hospital das Clinicas da Faculdade de Medicina da Universidade de São Paulo, no período de dezembro de 2004 a novembro de 2005

\begin{tabular}{lcc}
\hline Unhas das mãos acometidas & N & $\%$ \\
\hline Primeiro & 8 & 7,55 \\
Primeiro e outros & 11 & 10,38 \\
Outros & 1 & 0,94 \\
\hline Total & $\mathbf{2 0}$ & $\mathbf{1 0 0}$ \\
\hline
\end{tabular}

Nota: Qui-quadrado, $p=0,1208$

Observa-se nas tabelas 27 e 28 que as unhas acometidas, tanto nas mãos quanto nos pés, não exercem influência sobre o resultado da cultura.

Dos 106 doentes com cultura positiva, 105 apresentam também Micológico Direto positivo, enquanto apenas 1 apresenta este exame negativo. 
Tabela 28 - Distribuição quanto ao agente infeccioso por sexo e local de acometimento nos doentes com cultivo para fungos positivo, atendidos no ambulatório de Dermatologia do Hospital das Clinicas da Faculdade de Medicina da Universidade de São Paulo, no período de dezembro de 2004 a novembro de 2005

\begin{tabular}{|c|c|c|c|c|c|c|c|c|c|c|c|c|}
\hline \multirow{4}{*}{ Cultura } & \multicolumn{12}{|c|}{ Sexo } \\
\hline & \multicolumn{4}{|c|}{ Feminino } & & & \multicolumn{4}{|c|}{ Masculino } & \multirow{2}{*}{\multicolumn{2}{|c|}{ Total }} \\
\hline & \multicolumn{2}{|c|}{ Pés } & \multicolumn{2}{|c|}{ Mãos } & \multicolumn{2}{|c|}{ Total } & \multicolumn{2}{|r|}{ Pés } & \multicolumn{2}{|c|}{ Mãos } & & \\
\hline & $\mathbf{n}$ & $\%$ & $\mathrm{n}$ & $\%$ & $\mathbf{N}$ & $\%$ & $n$ & $\%$ & $\mathbf{n}$ & $\%$ & $\mathbf{n}$ & $\%$ \\
\hline Dermatófito & 49 & 83,05 & 2 & 15,38 & 51 & 70,83 & 34 & 94,44 & 5 & 71,43 & 39 & 90,70 \\
\hline FFND & 8 & 13,56 & 2 & 15,38 & 10 & 13,89 & 1 & 2,78 & - & - & 1 & 2,33 \\
\hline Levedura & 2 & 3,39 & 9 & 69,23 & 11 & 15,28 & 1 & 2,78 & 2 & 28,57 & 3 & 6,98 \\
\hline Total & 59 & 100,00 & 13 & 100,00 & 72 & 100,00 & 36 & 100,00 & 7 & 100,00 & 43 & 100,00 \\
\hline
\end{tabular}

Tanto nos homens quanto nas mulheres, a maioria das infecções ocorreu nas unhas dos pododáctilos. Os dermatófitos foram os fungos mais frequentemente isolados nas unhas dos pododáctilos e as leveduras nas unhas dos quirodáctilos (Tab. 28). 


\subsection{Caracterização dos doentes com onicomicose por Fungos filamentosos não dermatófitos}

Dentre os doentes com onicomicose, nove apresentaram fungos filamentosos não dermatófitos como agente etiológico. A idade mínima destes doentes foi de 36 anos e a idade máxima foi de 59 anos. A idade média foi de 46,6 anos, a mediana 44 anos, com desvio padrão de 7,9.

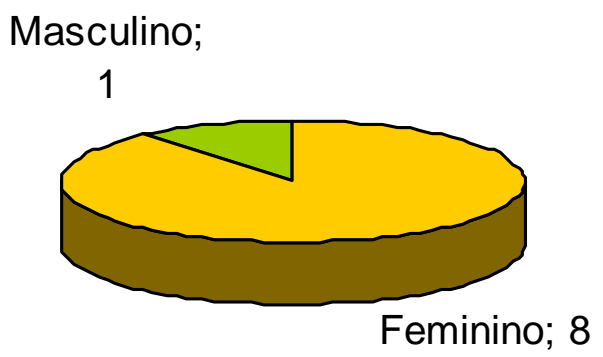

Figura 4 - Distribuição quanto ao gênero nos doentes com onicomicose causada por fungos filamentosos não dermatófitos, atendidos no ambulatório de Dermatologia do Hospital das Clinicas da Faculdade de Medicina da Universidade de São Paulo, no período de dezembro de 2004 a novembro de 2005

Aproximadamente $89 \%$ dos doentes eram do sexo feminino (Fig. 4), enquanto que na população estudada as mulheres constituíam $66,83 \%$ do total de doentes com suspeita de onicomicose..A proporção de mulheres com unhas acometidas por fungos filamentosos não dermatófitos foi de $7,34 \%$ do total das mulheres com exame micológico direto positivo e a dos homens $1,64 \%$ do total de homens com exame micológico direto positivo. 
Tabela 29 - Distribuição quanto ao tempo de evolução de doença nos doentes com onicomicose causada por fungos filamentosos não dermatófitos, atendidos no ambulatório de Dermatologia do Hospital das Clinicas da Faculdade de Medicina da Universidade de São Paulo, no período de dezembro de 2004 a novembro de 2005

\begin{tabular}{lcccc}
\hline \multicolumn{5}{c}{ Tempo de evolução } \\
\hline \\
\cline { 2 - 5 } & $\mathbf{N}$ & $\%$ & $\mathbf{f a}$ & $\%$ \\
Até 1 ano & 1 & 12,50 & 1 & 12,50 \\
De 1 até 2 & 1 & 12,50 & 2 & 25,00 \\
De 2 até 3 & 1 & 12,50 & 3 & 37,50 \\
De 4 até 5 & 2 & 25,00 & 5 & 62,50 \\
Mais de 10 & 3 & 37,50 & 8 & 100,00 \\
\hline
\end{tabular}

Nota: $f a=$ freqüência acumulada

Nestes casos, pode-se observar que quase $40 \%$ dos doentes apresentavam uma evolução arrastada, por mais de dez anos (Tab. 29). 
Tabela 30 - Distribuição quanto a tratamentos anteriores para onicomicose nos doentes com onicomicose causada por fungos filamentosos não dermatófitos, atendidos no ambulatório de Dermatologia do Hospital das Clinicas da Faculdade de Medicina da Universidade de São Paulo, no período de dezembro de 2004 a novembro de 2005

Tratamentos anteriores

\begin{tabular}{lcc}
\hline & $\mathbf{N}$ & $\%$ \\
\hline Não & 4 & 44,44 \\
Sim & 5 & 55,56 \\
\hline
\end{tabular}

Neste grupo, aproximadamente $55 \%$ das pessoas referiam tratamentos anteriores para onicomicose (Tab. 30). O acometimento das unhas do hálux (Tab. 31) e do polegar (Tab. 32) foi semelhante à dos outros grupos.

Tabela 31 - Distribuição quanto aos pododáctilos acometidos nos doentes com onicomicose causada por fungos filamentosos não dermatófitos, atendidos no ambulatório de Dermatologia do Hospital das Clinicas da Faculdade de Medicina da Universidade de São Paulo, no período de dezembro de 2004 a novembro de 2005

\begin{tabular}{llc}
\hline Pododáctilos acometidos & N & $\%$ \\
\hline Primeiro somente & 6 & 66,67 \\
Primeiro e outros & 3 & 33,33 \\
\hline
\end{tabular}

Tabela 32 - Distribuição quanto ao acometimento das unhas dos quirodáctilos nos doentes com onicomicose causada por fungos filamentosos não dermatófitos, atendidos no ambulatório de Dermatologia do Hospital das Clinicas da Faculdade de Medicina da Universidade de São Paulo, no período de dezembro de 2004 a novembro de 2005

\begin{tabular}{lcc}
\hline Unhas dos quirodáctilos & N & $\%$ \\
\hline Primeiro e outros & 2 & 22,22 \\
Nenhum & 7 & 77,78 \\
\hline
\end{tabular}


Tabela 33 - Distribuição quanto à presença de tinea pedis e/ou tinea manuum nos doentes com onicomicose causada por fungos filamentosos não dermatófitos, atendidos no ambulatório de Dermatologia do Hospital das Clinicas da Faculdade de Medicina da Universidade de São Paulo, no período de dezembro de 2004 a novembro de 2005

\begin{tabular}{lcc}
\hline Tinea & N & $\%$ \\
\hline Nenhum & 6 & 66,67 \\
Tinea pedis & 3 & 33,33 \\
\hline Total & 9 & 100,00 \\
\hline
\end{tabular}

A maioria dos doentes com unhas acometidas por fungos filamentosos não dermatófitos não apresentavam tinea pedis associada (Tab. 33). As profissões se distribuíram igualitariamente (Tab. 34).

Tabela 34 - Distribuição quanto à profissão nos doentes com onicomicose causada por fungos filamentosos não dermatófitos, atendidos no ambulatório de Dermatologia do Hospital das Clinicas da Faculdade de Medicina da Universidade de São Paulo, no período de dezembro de 2004 a novembro de 2005

\begin{tabular}{ll}
\hline Profissão & N \\
\hline Aposentado & 2 \\
Auxiliar de enfermagem & 2 \\
Do lar & 2 \\
Empregada doméstica & 1 \\
Não respondeu & 1 \\
Oficial administrador & 1 \\
\hline Total & 9 \\
\hline
\end{tabular}


Quanto à classificação das onicomicoses, todos os doentes com infecção ungueal causada por FFND apresentavam onicomicose subungueal distal (Fig. 5).

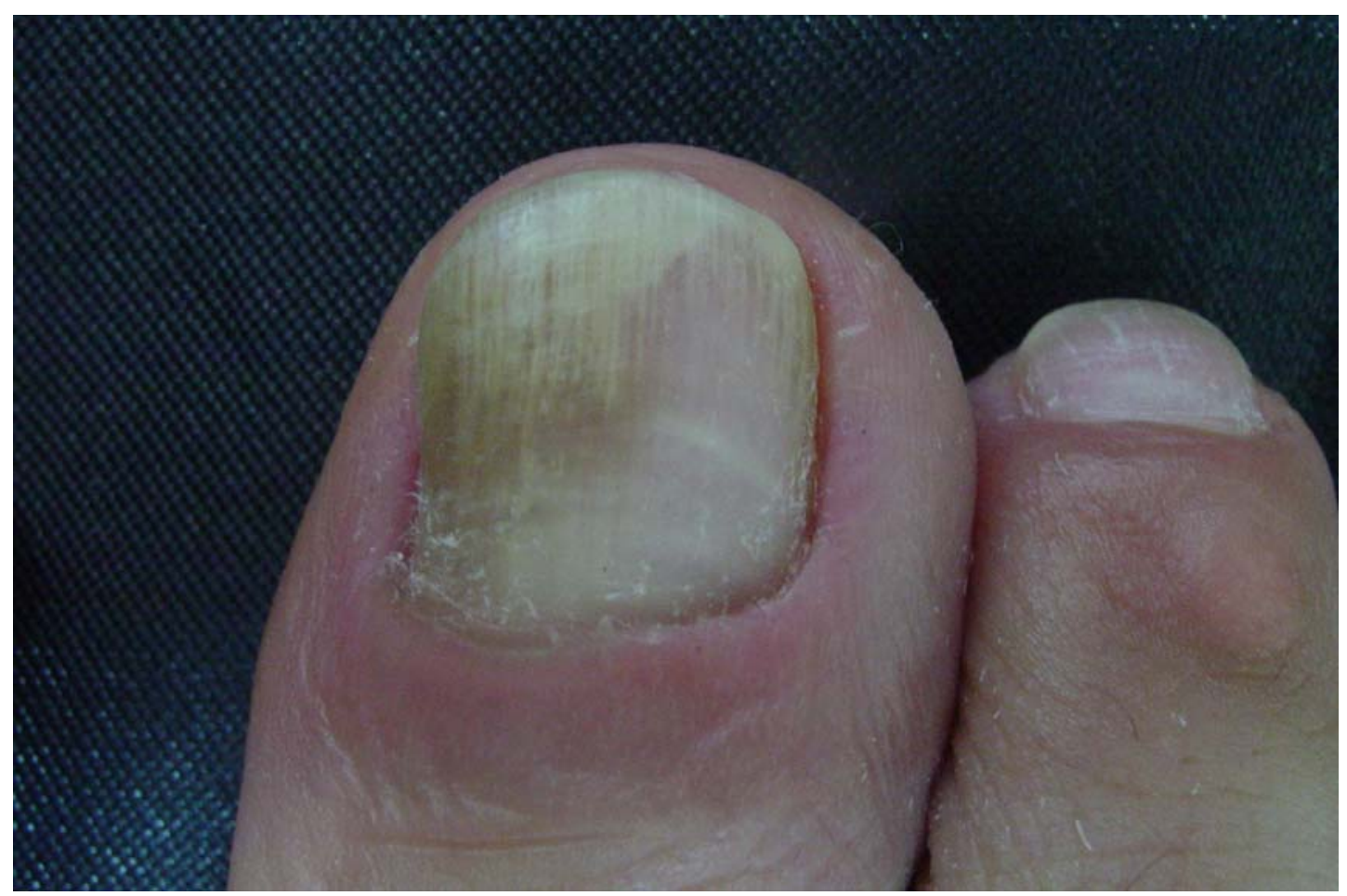

Figura 5 - Quadro clínico nos doentes com onicomicose causada por fungos filamentosos não dermatófitos, atendidos no ambulatório de Dermatologia do Hospital das Clinicas da Faculdade de Medicina da Universidade de São Paulo, no período de dezembro de 2004 a novembro de 2005: onicomicose subungueal distal causada por Scytalidium lignicola - unhas dos pododáctilos apresentando hiperceratose subungueal 
Em todos os casos de onicomicose causada por FFND, o exame micológico direto sugeriu que se tratava de FFND: no caso de Scytalidium dimidiatum notou-se a presença de hifas septadas demáceas (Fig. 6); a presença de conídios castanho-ocre ocorreu no caso de Aspergillus sp e microconídio bicelular, no exame micológico direto de Fusarium solani.

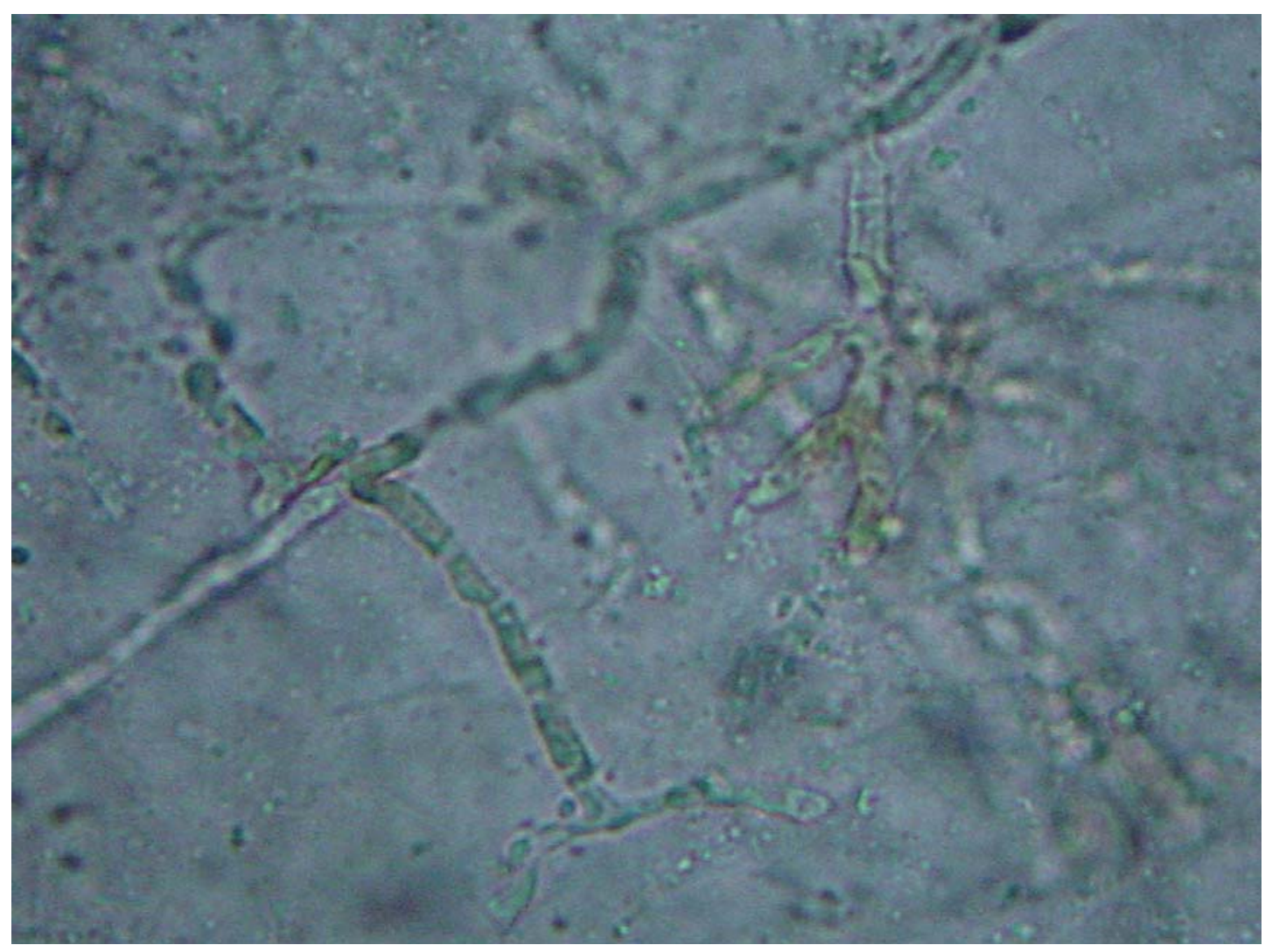

Figura 6 - Exame micológico direto de raspado de unha com hidróxido de potássio $(\mathrm{KOH})$ a $10 \%$ e dimetilssulfóxido (DMSO) a $40 \%$ nos doentes com onicomicose causada por fungos filamentosos não dermatófitos, atendidos no ambulatório de Dermatologia do Hospital das Clinicas da Faculdade de Medicina da Universidade de São Paulo, no período de dezembro de 2004 a novembro de 2005 - demonstração de artroconídios e hifas septadas de coloração ocre (400x) 
Tabela 35 - Distribuição quanto à espécie fúngica isolada nos doentes com onicomicose causada por fungos filamentosos não dermatófitos, atendidos no ambulatório de Dermatologia do Hospital das Clinicas da Faculdade de Medicina da Universidade de São Paulo, no período de dezembro de 2004 a novembro de 2005

\begin{tabular}{lll}
\hline Patógeno & N & $\%$ \\
\hline FFND & & \\
Scytalidium dimidiatum & 6 & 66,67 \\
Fusarium solani & 2 & 22,22 \\
Aspergillus sp & 1 & 11,11 \\
\hline
\end{tabular}

Nota: FFND = fungos filamentosos não dermatófitos

O Scytalidium dimidiatum foi o FFND mais freqüente (Tab. 35). 
6. Discussão 
As infecções ungueais possuem epidemiologia multifatorial sendo que a sua prevalência é influenciada pela idade, estilo de vida e presença de doença concomitante. Além disso, a distribuição dos diversos patógenos de onicomicose não é uniforme, pois depende de vários fatores tais como a geografia e o clima da região, além de migração da população (Faergemann \& Baran, 2003). Ou seja, a ecologia e a epidemiologia da onicomicose variam de acordo com a região geográfica.

O diagnóstico de onicomicose foi aqui estabelecido em 170 doentes, pelo exame micológico direto positivo, dentre os 205 indivíduos que apresentavam suspeita clínica de onicomicose. Foram investigados alguns aspectos nos indivíduos com exame micológico direto positivo ( $\mathrm{N}=170)$, nas pessoas com identificação da espécie fúngica por cultura ( $N=106)$ e naquelas com o diagnóstico de onicomicose por FFND (N=9).

Dentre os que apresentavam o exame micológico direto positivo, a cultura foi positiva em $61,75 \%(\mathrm{~N}=105)$. Este achado está de acordo com a literatura: Elewski (1997) obteve 2065 espécimes ungueais com o exame micológico direto positivo em 1707 (82\%), dentre estes, a cultura para fungos foi positiva em 1069 (62,6\%).

A discrepância entre o exame micológico direto positivo e cultivo negativo pode ser explicada pela distribuição irregular dos fungos nas lesões; a dificuldade de coleta adequada do material, especialmente quando 
é do tipo subungueal; a facilidade com que se contaminam as culturas, devido aos fungos ambientais e a microbiota bacteriana que dificulta a identificação do verdadeiro agente etiológico. Além disso, podem ser incluídas as limitações inerentes ao exame, como a intensa queratinização do material ungueal, que dificulta a observação microscópica dos microorganismos e a viabilidade fúngica, que pode resultar em culturas falso negativas devido a tratamentos anteriores, mesmo após a suspensão o medicamento uma semana antes da coleta (Carvalho,1990, Martelozzo, 2005), além do crescimento de fungos contaminantes, impedindo o crescimento do verdadeiro patógeno (Carvalho,1990).

Quanto à onicomicose por FFND, neste trabalho todos os nove doentes apresentavam exame micológico direto positivo, sendo este um dos critérios diagnósticos de onicomicose causada por fungos saprófitas; juntamente com a alteração ungueal clinicamente consistente com a hipótese diagnóstica; ausência de crescimento de fungos dermatófitos e crescimento do mesmo FFND em duas coletas repetidas em datas diferentes, com intervalo de pelo menos uma semana.

A prevalência de onicomicose foi igual em ambos os sexos, quando se comparou a porcentagem de pessoas afetadas em cada sexo com a sua proporção na composição da amostra $(p=0,1023)$. Esses dados concordam com Roberts (1992) que não observou diferença quanto ao sexo. A literatura é controversa: alguns autores observaram preponderância do sexo feminino sobre o masculino, com valores entre 67 e 74\% de onicomicose (Sais et al, 1995; Madrenys-Brunet, 1996; Mercantini et al., 1996; Luque et al., 1997; 
Vélez et al., 1997; Lopes et al., 1999; Koussidou et al, 2002; Araújo et al., 2003b; Alvarez et al, 2004). Enquanto outros (Gupta et al, 2000; Perea et al., 2000) observaram exatamente o contrário, com cerca de $64 \%$ dos casos ocorrendo no sexo masculino. A justificativa para estas discrepâncias talvez esteja na composição populacional de onde as amostras foram escolhidas, uma vez que a infecção fúngica depende de ecologia e hábitos culturais, como já dito anteriormente.

Já os doentes com onicomicose causada por FFND apresentavam uma nítida predominância no sexo feminino (8:1), fato inédito na literatura. Devido à exigüidade de casos, sugere-se aprofundamento deste tópico, investigando-se a influência de fatores hormonais, culturais e ambientais.

$\mathrm{Na}$ literatura, os autores justificam o aumento da prevalência da onicomicose com o avançar da idade pela circulação periférica mais lenta, presença de comorbidades - diabetes, trauma ungueal repetitivo, exposição aos fungos patogênicos por mais tempo, imunidade sub-ótima, inatividade, ou a inabilidade para cortar as unhas dos pododáctilos ou manter cuidados com os pés. Por outro lado, a razão para que a prevalência de onicomicose seja menor nas crianças do que nos adultos, poderia ser justificado pelo fato daquele grupo apresentar um crescimento ungueal mais acelerado, ter menos tempo de exposição aos agentes fúngicos, ter menor prevalência de tinea pedis, menor extensão ungueal para invasão (Elewski, 1998). Neste trabalho, a idade da população com suspeita de onicomicose e a idade da população com exame micológico direto positivo apresentaram valores semelhantes, com variância acentuada (5 a 89 anos de idade) e com 
mediana nos 49 anos. Não podemos considerar esta população como representativa da população geral.

Já nos casos de onicomicose causada por FFND, embora a amostra seja muito pequena (apenas 9 casos), pode-se observar que a variância foi muito mais estreita (36 a 59 anos) com a mediana nos 44 anos, ou seja, atingiu mais a faixa etária da meia idade, idade laboral produtiva.

Tanto nos homens quanto nas mulheres, a maioria das infecções ocorreu nas unhas dos pododáctilos, o que também ocorreu no Rio Grande do Sul (Lopes et at, 1999), Rio de Janeiro (Araújo et al, 2003), Espanha (Sais et al, 1995), Canadá (Gupta et al, 2000), Grécia (Koussidou et al, 2002) e na Colômbia (Alvarez et al, 2004). A justificativa para este fato pode ser porque as unhas dos pododáctilos apresentam velocidade de crescimento menor do que as dos quirodáctilos e porque a ocorrência de tinea pedis é maior do que a de tinea manuum. Dentre os pododáctilos, o primeiro foi o mais acometido, coincidindo com os dados de Achten \& Wanet-Rouard (1978), Gupta et al (2000).

Neste trabalho, todos os grupos estudados apresentaram comportamento semelhante ao relatado na literatura.

Zaias (1992) classifica a onicomicose em quatro tipos clínicos: subungueal distal e/ou lateral, subungueal proximal, superficial branca e distrófica total, associada à candidíase muco cutânea crônica.

Neste estudo, em todos os grupos estudados, o tipo clínico mais encontrado foi o subungueal distal e/ou lateral, coincidindo com os achados de Gupta et al (1997) e Gupta et al (2000). 
Ghannoum et al (2000) cita tinea pedis como um fator predisponente para onicomicose, sendo que a onicomicose ocorre 3 vezes mais nestes indivíduos.

Aqui a maioria dos doentes com o diagnóstico de onicomicose $(\mathrm{N}=$ 170) apresentava tinea pedis associada $(p<0,0001)$. No entanto, naqueles casos com o diagnostico de onicomicose por FFND isto não se observou, havendo 3 doentes com esta associação dentre os 9 considerados.

Segundo Gupta \& Konnikov (1998), o risco de contrair onicomicose para a população diabética estaria aumentado em 2,77 vezes em relação à população geral. Entretanto, Romano et al (2001) não demonstraram freqüência maior de onicomicose em pacientes diabéticos em relação ao controle. Aqui não se encontrou associação entre onicomicose e comorbidades $(p=0,3851)$ na população com exame micológico direto positivo $(\mathrm{N}=170)$.

Os dermatófitos são os agentes responsáveis pela maioria das onicomicoses, representando cerca de 69 a 80\% destas infecções (Gupta et al, 1997b; Lopes 1999; Gupta et al,2000, Ghannoum, 2000). Outros autores (Martelozzo et al, 2005) encontraram proporções diferentes: 33,85\% para fungos dermatófitos, 52,17\% para leveduras e 13,97\% para FFND.

Neste trabalho, considerando-se as unhas dos pododáctilos e dos quirodáctilos num só grupo, os dermatófitos foram os fungos responsáveis pela maioria das infecções no grupo de doentes com cultura para fungos positiva $(\mathrm{N}=106)$, sendo encontrados em $78,52 \%(\mathrm{~N}=84)$ das culturas, as leveduras foram o agente da onicomicose em $13,08 \%(\mathrm{~N}=14)$ dos casos e os 
fungos filamentosos não dermatófitos foram considerados patógeno em $8,40 \%(\mathrm{~N}=9)$ das vezes. Um dos doentes apresentava 2 agentes patogênicos distintos nas unhas quirodáctilos e pododáctilos.

Observou-se nesta amostra concordância com os dados da literatura em relação à freqüência dos dermatófitos como causa de onicomicose, entretanto ressalta-se a freqüência relativamente alta de onicomicose por FFND.

Por outro lado, quando se distingue a onicomicose das unhas dos quirodáctilos daquelas dos pododáctilos, as leveduras alcançam preponderância na infecção das unhas das mãos, como referido por Lopes et al (1999) no Rio Grande do Sul; Araújo et al (2003) no Rio de janeiro; Koussidou et al (2002) na Grécia e Alvarez et al (2004) na Colômbia. Entretanto Gupta et al (2000), no Canadá não notaram estas diferenças nos quirodáctilos, encontrando dermatófitos e leveduras como responsáveis pelo mesmo número de casos.

Considerou-se neste trabalho como onicomicose por leveduras somente os casos nos quais o exame micológico direto mostrava a presença de pseudo-hifas e blastoconídios associado ao isolamento de tal fungo na cultura. Houve, nesta casuística, 28 casos com contaminação por Candida sp.

Neste trabalho, os dermatófitos foram os fungos mais freqüentemente isolados nas unhas dos pododáctilos e as leveduras nas unhas dos quirodáctilos, coincidindo com alguns dos autores acima. Considerando as infecções dos pododáctilos separadamente dos quirodáctilos, as leveduras foram responsáveis por 3,1\% e $60 \%$, respectivamente, naquele grupo de 
identificação do fungo por cultura $(\mathrm{N}=160)$. Isto provavelmente se deve aos hábitos de vida, que expõem as mãos a água mais do que os pés.

Dentre as espécies fúngicas responsáveis por onicomicose humana, o T.rubrum é a mais prevalente (Lopes et al 1999, Sais et al 1995, Gupta et al 2000, Koussidou et al 2002, Alvarez et al 2004, Ghannoum et al 2000, Kemna e Elewski 1996). Já Araújo et al (2003) e Martelozzo et al (2005) observaram espécies de Candida como os agentes mais freqüentes nesta doença.

Nosso estudo concorda em que $T$. rubrum seja a espécie de dermatófito mais comumente responsável por onicomicose.(63,56\%), no grupo de pessoas com o diagnóstico de onicomicose com identificação do agente por cultura $(\mathrm{N}=106)$.

Neste estudo, a maioria dos casos de onicomicose superficial branca foi causada por Trichophyton mentagrophytes (3/4), coincidindo com os dados de Zaias (1966) e Gupta et al (1997).

Quanto ao T. tonsurans, os dados deste estudo (freqüência de 7,48\% dentre os casos com cultura para fungos positive) coincidem com outros estudos em São Paulo (Ruiz e Zaitz, 1996; Chimelii et al, 2003) e diferem dos de outras publicações referentes a Santa Catarina e Rio de Janeiro (Coelho, 2005; Costa et al 1991), os quais referem freqüências bem mais baixas. Existe uma teoria que esta discrepância se deveria a correntes migratórias do Nordeste do Brasil para São Paulo (Ruiz e Zaitz, 1996).

Embora os dermatófitos ainda sejam os principais agentes etiológicos das onicomicoses, algumas espécies de FFND podem causar onicomicose. No nosso estudo $8,4 \% \quad(N=9)$ das onicomicoses foram 
causadas por tais fungos. Tosti et al, (2000) observaram 13,6\% das onicomicoses causadas por FFND.

Assim como na tinea unguium, a onicomicose causada por FFND ocorreu bem mais comumente nas unhas dos pododáctilos do que nas unhas dos quirodáctilos, concordando com a literatura (English,1976; Tosti et al,2000).

A freqüência de onicomicose causada por FFND varia de local para local, assim como variam as espécies causadoras da onicomicose. No presente estudo o FFND mais encontrado foi Scytalidium dimidiatum, fungo não observado no trabalho de Tosti et al (2000), na Itália. Provavelmente porque o Scytalidium dimidiatum é associado à onicomicose em países tropicais, como África, Índia, Caribe e paises da América do sul. Lacroix et al (2003) em um estudo feito em Paris observou que a grande maioria dos casos havia visitado ou morado em paises tropicais ou subtropicais. Campbell \& Mulder (1977) relataram casos de tinea pedis e ou onicomicose causados por Scytalidium hialinum na Inglaterra, porém os doentes eram imigrantes da Jamaica, Nigéria e Sierra Leone. Moore (1986) encontrou em imigrantes da América do Sul, Índia e África casos de infecção da pele dos pés, mãos, unhas dos pés e mãos por Scytalidium lignicola ou Scytalidium hialinum.

Alvarez et al (2004), na Colômbia, encontrou 8 casos de onicomicose causada por Scytalidium dimidiatum, entre 183 casos de onicomicose, que ao lado de Fusarium spp foram os FFND mais encontrados. Lacaz et al (1999) estudaram 2 casos de onicomicose por Scytalidium dimidiatum no 
Brasil. Araújo et al, Lopes et al (2003), Coelho et al (2005) e Pontarelli et al (2005) também isolaram Scytalidium dimidiatum como agente de onicomicose no Brasil.

Em nosso estudo a onicomicose por FFND não esteve associada com características clínicas peculiares. O quadro clínico observado foi o subungueal distal em todos os 9 casos, quadro clínico indistinguível da onicomicose por dermatófitos, concordando com as observações de Campbell et al (1973) e Moore (1986).

Em todos os casos de onicomicose causada por FFND, o exame micológico direto já era sugestivo de que se tratava de FFND: no caso de Scytalidium dimidiatum notou-se a presença de hifas septadas demáceas; a presença de conídios castanho-ocre ocorreu no caso de Aspergillus sp e microconídio bicelular, no exame micológico direto de Fusarium solani. O exame micológico direto compatível com o agente isolado é um dos critérios para o diagnóstico de onicomicose por fungos oportunistas.

Em resumo, casos de onicomicose causados por FFND não são tão raros quanto se esperaria que fosse em um grande centro urbano, como São Paulo. Assim, seja qual for a situação, a investigação de onicomicose deve alcançar a identificação do agente etiológico para que se faça um bom planejamento terapêutico. 


\section{Conclusões}

(2)


Dentre os 205 indivíduos clinicamente suspeitos de onicomicose, houve a confirmação laboratorial por exame micológico direto em 170 pessoas, ou seja estabeleceu-se o diagnostico laboratorial de onicomicose em $82,93 \%$ dos doentes.

Dentre os 205 indivíduos clinicamente suspeitos de onicomicose, foi possível a identificação da espécie fúngica responsável pela onicomicose por 106 doentes $(51,71 \%)$.

Dentre os 170 indivíduos com onicomicose confirmada pelo exame micológico direto, foi possível a identificação da espécie fúngica 106 doentes $(62,35 \%)$.

Dentre os 107 fungos isolados como agentes de onicomicose, os dermatófitos foram identificados em $78,52 \%(\mathrm{~N}=84)$, as leveduras em $13,08 \%(\mathrm{~N}=14)$ e os FFND em $8,40 \%(\mathrm{~N}=9)$ das vezes

Os 84 dermatófitos encontrados no total da amostra identificada foram: Trichophyton rubrum $(63,56 \%)$ e Trichophyton mentagrophytes ou Trichophyton tonsurans ( $7,48 \%$ cada).

As leveduras, Candida albicans e Candida sp ocorreram em 6,54\%, cada uma, no total das amostras identificadas.

Dentre os FFND, Scytalidium dimidiatum foi o agente em 5,62\%, Fusarium solani em 1,87\% e Aspergillus sp em 0,91\% do total de 107 amostras identificadas. 
As pessoas com onicomicose por FFND referiam tratamentos anteriores com maior freqüência e quadro clínico mais arrastado do que aquelas com onicomicose por outros agentes, na amostra estudada.

Ao contrário da onicomicose causada por dermatófitos, a onicomicose causada por FFND ocorreu principalmente na mulher, não ocorreu na infância e não se associou a tinea pedis, na amostra estudada.

A apresentação clínica da unha com onicomicose por FFND foi indistinguível daquela por dermatófitos ou candidose, nesta amostra.

A investigação da onicomicose deve alcançar a identificação do agente etiológico, para que se faça um bom planejamento terapêutico, já que os fungos filamentosos não dermatófitos ocorrem com freqüência considerável e as onicomicoses por eles causadas são indistinguíveis daquelas ocasionadas por dermatófitos. 
8. Anexos 


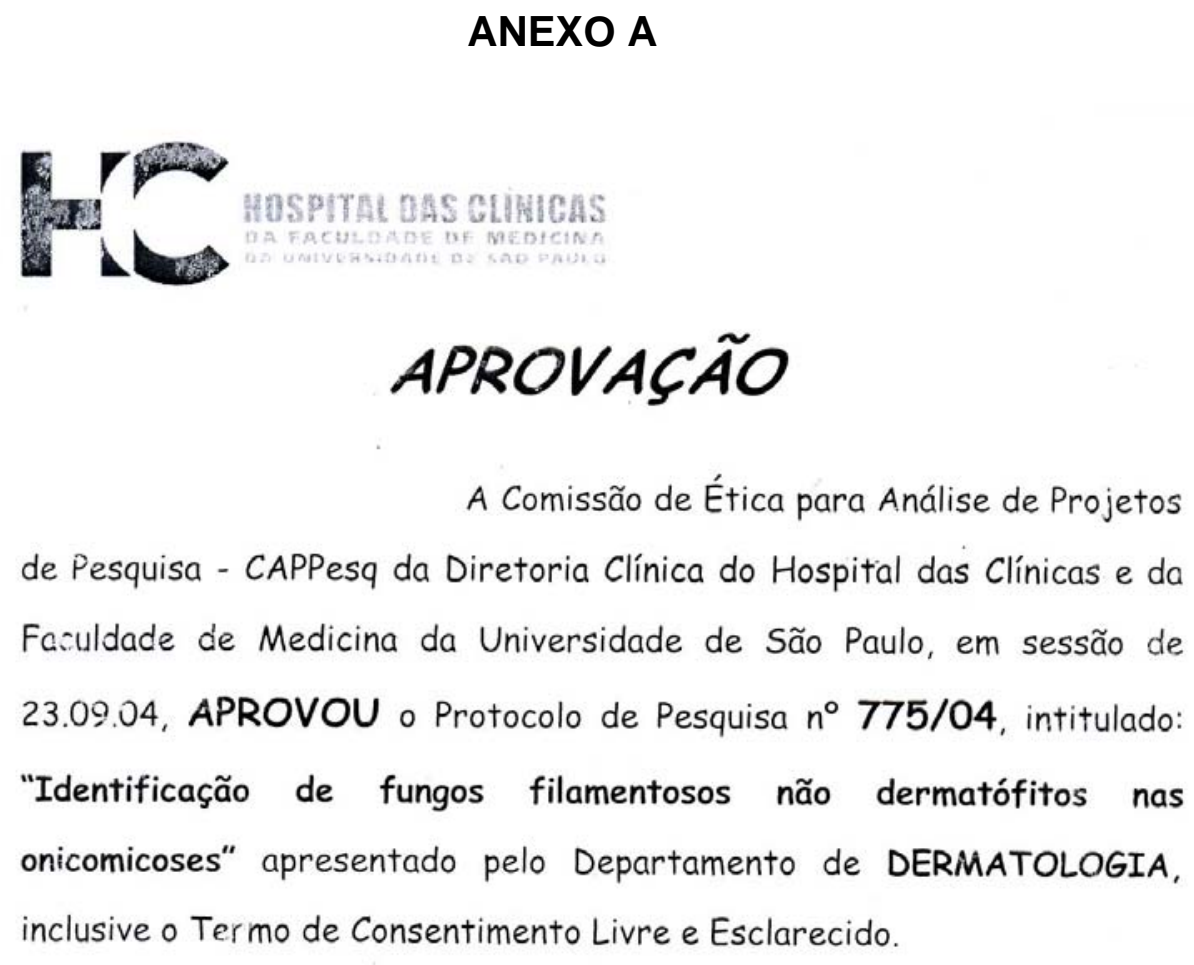

Pesquisador(a) Responsável: Profa. Dra. Cidia Vasconcellos

Pesquisador(a) Executante: Dra. Simone Felizardo Rocha de Souza

CAPPesq, 23 de Setembro de 2004.

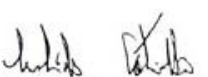

PROF. DR. EUCLIDES AYRES DE CASTILHO

Presidente da Comissão de Ética para Análise de Projetos de Pesquisa

\footnotetext{
OBSERVAÇÃO: Cabe ao pesquisador elaborar e apresentar à CAPPesq, os relatórios parciais e final soúre a pesquisa (Resolução do Conselho Nacional de Saúde $n^{\circ} 196$, de 10.10.1996, inciso IX.2, letra "c")
}

Comissão de Ética para Análise de Projetos de Pesquisa do HCFMUSP e da FMUSP

Diretoria Clínica do Hospital das Clínicas da Faculdade de Medicina da Universidade de São Paulo

Rua Ovidio Pires de Campos. $255,5^{\circ}$ andar - CEP 05430010 - São Paulo - SP
Fone: 011 - 30696442 fax : 011 - 30696492 - e-mail : cappesq@henet.usp.br / secretariacappesq@hcnet.usp.br 


\section{ANEXO B}

\section{TERMO DE CONSENTIMENTO LIVRE E ESCLARECIDO}

\section{I - DADOS DE IDENTIFICAÇÃO DO SUJEITO DA PESQUISA OU RESPONSÁVEL LEGAL}

1.NOME DO PACIENTE.:

DOCUMENTO DE IDENTIDADE $\mathrm{N}^{\circ}$ : SEXO : .M F DATA NASCIMENTO: ....................... ENDEREÇO $\mathrm{N}^{\circ}$ APTO

BAIRRO: CIDADE

CEP

TELEFONE: DDD .)

2.RESPONSÁVEL LEGAL

NATUREZA (grau de parentesco, tutor, curador etc.)

DOCUMENTO DE IDENTIDADE :

SEXO: $M \quad F$

DATA NASCIMENTO.: .....................

ENDEREÇO

$\mathrm{N}^{0}$

APTO:

BAIRRO: CIDADE:

CEP

TELEFONE:DDD (........)

\section{II - DADOS SOBRE A PESQUISA CIENTÍFICA}

\section{TÍTULO DO PROTOCOLO DE PESQUISA}

\section{Identificação de fungos filamentosos não dermatófitos nas onicomicoses}

PESQUISADOR : Profa Dra Cidia Vasconcellos

CARGO/FUNÇÃO: Médica, LIM 53 HC-FMUSP

INSCRIÇÃO CONSELHO REGIONAL Nº 35.713

UNIDADE DO HCFMUSP: Departamento de Dermatologia

3. AVALIAÇÃO DO RISCO DA PESQUISA:

$$
\begin{aligned}
& \text { SEM RISCO } \\
& \text { RISCO BAIXO }
\end{aligned}
$$

\section{RISCO MÍNIMO $\quad$ X RISCO MÉDIO RISCO MAIOR}




\section{III - REGISTRO DAS EXPLICAÇÕES DO PESQUISADOR AO PACIENTE OU SEU REPRESENTANTE LEGAL SOBRE A PESQUISA CONSIGNANDO:}

\section{1. justificativa e os objetivos da pesquisa -}

Você ou seu filho está sendo convidado a participar de uma pesquisa clínica, que tem como objetivo o estudo de agentes causadores de onicomicoses. Esta pesquisa busca avaliar a freqüência de fungos denominados fungos filamentosos não-dermatofitos.

Antes de tomar uma decisão é importante que você compreenda porque esta pesquisa clínica está sendo realizada e o que ela envolverá. Por favor, leia com atenção este documento, faça as perguntas que desejar e pense bem antes de concordar.

Sinta-se à vontade para perguntar sobre quaisquer dúvidas ou para pedir maiores informações ao seu médico antes de tomar uma decisão sobre sua participação. Se, após a leitura destas informações, você não concordar em participar da pesquisa, não haverá qualquer prejuízo quanto ao seu tratamento ou de seu filho no atendimento prestado por este hospital.

Se você escolher participar, você poderá retirar seu consentimento a qualquer momento e você ou seu filho deixará de participar do estudo, sem que haja qualquer prejuízo quanto à continuidade de seu tratamento pelo mesmo hospital, devendo apenas informar ao médico responsável o motivo que o levou a se retirar do estudo.

O objetivo deste estudo é verificar a freqüência de um determinado fungo como agente de onicomicose (micose na unha). Estes fungos em estudo são denominados fungos filamentosos não-dermatofitos.

2. procedimentos que serão utilizados e propósitos, incluindo a identificação dos procedimentos que são experimentais: será feita a coleta de material - obtido por raspado debaixo da unha doente e a partir deste material s

Se você decidir participar ou autorizar a participação do seu filho e assinar este Termo de Consentimento Livre e Esclarecido, você responderá a um questionário sobre sua doença e, após, será submetido a coleta do material, a qual é feita raspando a unha. O material obtido será enviado para que seja feito um exame que é chamado cultura. Esta cultura visa a identificação do agente (fungo) da doença da unha. O resultado da culltura poderá ser retirado em 4 semanas.

\section{3. desconfortos e riscos esperados:}

como será colhido material por raspado debaixo da unha, poderá haver desconforto, que geralmente não ocorre e quando acontece é de pequena intensidade.

A coleta do mateiral (raspado da unha) geralmente não acarreta desconforto. Pode haver dor se a unha já for uma unha sensível. 
4. benefícios que poderão ser obtidos $O$ beneficio é descobrir qual é o fungo que está causando a doença da sua unha ou da unha do seu filho.

5. procedimentos alternativos que possam ser vantajosos para o indivíduo

\section{IV - ESCLARECIMENTOS DADOS PELO PESQUISADOR SOBRE GARANTIAS DO SUJEITO DA PESQUISA CONSIGNANDO:}

1. acesso, a qualquer tempo, às informações sobre procedimentos, riscos e benefícios relacionados à pesquisa, inclusive para dirimir eventuais dúvidas.

Você tem o direito de questionar o médico responsável pelo acompanhamento de seu caso ou de seu filho a qualquer momento, no sentido de esclarecer todas as dúvidas decorrentes do estudo em questão, sejam elas relacionadas com os riscos, benefícios ou quaisquer outros assuntos ligados a este estudo. Se você tiver dúvidas sobre seus direitos e deveres durante a participação no estudo, você deve esclarecê-los com o seu médico.

2. liberdade de retirar seu consentimento a qualquer momento e de deixar de participar do estudo, sem que isto traga prejuízo à continuidade da assistência.

Você poderá retirar seu consentimento ou do seu filho, a qualquer momento e deixar de participar do estudo, sem que haja qualquer prejuízo quanto à continuidade de seu tratamento ou do seu filho pela mesma instituição, devendo apenas informar ao médico responsável o motivo que o levou a abandonar o estudo, para que esta informação conste na avaliação global dos resultados obtidos com todos os pacientes.

3. salvaguarda da confidencialidade, sigilo e privacidade.

Em hipótese alguma você ou seu filho terão sua identidade divulgada para outras pessoas ou entidades, além daquelas que participam efetivamente do acompanhamento deste estudo. Estarão, também, mantidas em sigilo todas as informações obtidas e que estejam relacionadas com a sua privacidade ou de seu filho e não será possível sua identificação através de fotografias. 
4. disponibilidade de assistência no HCFMUSP, por eventuais danos à saúde, decorrentes da pesquisa.

Em caso de eventuais danos à sua saúde ou a do seu filho, o Hospital das Clínicas da FMUSP ficará a sua disposição, tanto para realização de exames como de internação

\section{5. viabilidade de indenização por eventuais danos à saúde decorrentes da pesquisa.}

Em caso de eventuais danos à sua saúde ou a do seu filho, o Hospital das Clínicas da FMUSP ficará a sua disposição para os procedimentos adequados, sem qualquer ônus de sua parte.

Dra Simone Felizardo Rocha de Souza Telefone celular 24 horas: 9540-1103

Profa. Dra. Cidia Vasconcellos Telefone celular 24 horas: 9714-5449

\section{VII - CONSENTIMENTO PÓS-ESCLARECIDO}

Declaro que, após convenientemente esclarecido pelo pesquisador e ter entendido o que me foi explicado, consinto em participar do presente Protocolo de Pesquisa

São Paulo, de de 20 


\section{ANEXO C}

\section{PROTOCOLO DE PESQUISA}

SERVIÇO DE DERMATOLOGIA - HOSPITAL DAS CLINICAS I FMUSP AMBULATORIO DE DERMATOLOGIA

\section{Prof. Dr José Eduardo Costa Martins}

IDENTIFICAÇÃo

NOME -

IDADE - SEXO ( ) M ( ) F COR PROFISSÃO

HÁBITOS

END

FONE

HISTORIA

Tempo de evolução

Sintomas dor ( )

Tratamentos anteriores $\operatorname{sim}()$ não ( )

secreção purulenta ( )

Quais =

Comorbidades - DM ( ) imunodepressão ( ) OUTRAS -

Medicações em uso -

ASPECTO CLÍNICO

Subungueal distal ( )

Subungueal proximal ( )

superficial ( )

Paroniquia associada ( )

total ( )

paquioniquia ( )

UNHAS ACOMETIDAS

Mãos ( )

pés ( )

Primeiro ( ) segundo ( ) terceiro ( ) quarto ( ) quinto ( )

TINEA PEDIS ASSOCIADA $\operatorname{sim}($ ) não ( )

COLORAÇÃO

ASS - 
9. Referências

th. Referencias 
Achten G, Wanet-Rouard J. Onychomycosis in the laboratory. Mycosen 1978; 23: 125.

Alvarez MI, González LA, Castro LA. Onychomycosis in Cali, Colômbia. Mycopathologia. 2004; 158: 181-6.

Alvarez P, Enríquez AM, Toro C, Martínez I, Buhigas I, Miguel S, Lago M, Puente S, Palacio A, Baquero M. Dermatomicosis de importación por Scytalidium dimidiatum: a propósito de tres casos. Rev Iberoam Micol 2000; 17: $102-6$.

Anaissie E, Kantarjian H, Ro J, Hopfer R, Rolston K, Fainstein V, Bodey G . The emerging role of Fusarium infections in patients with câncer. Medicine. 1988; 67: 77-83.

André J, Achten G. Onychomycosis. Int J Dermatol. 1987; 26: 481-90.

Aquino VR, Constante CC, Bakos, L. Freqüência das dermatofitoses em exames micológicos em Hospital Geral de Porto Alegre, Brasil. An Bras Dermatol. 2007; 82:239-44.

Araujo, A.J.G.; Souza M.A.J.; Bastos O.M.; Oliveira J.C. Onicomicoses por fungos emergentes: análise clínica, diagnóstico laboratorial e revisão. An Bras Dermatol. 2003; 78:445-55.

Ardehali M. Dermatophytic agents of tinea unguium in Iran. Int J Dermatol. 1973; 21: 322-3. 
Campbell CK, Kurwa A, Abdel-Aziz A-HM, Hodgson C. Fungal infection of skin and nails by Hendersonula toruloidea. $\mathrm{Br}$ J Dermatol. 1973; 89: 45-52.

Campbell CK, Mulder JL. Skin and nail infection by Scytalidium hyalinum sp. nov. Sabouraudia, 1977; 15: 161-6.

Carvalho MTF. Pesquisa de fungos em unhas de pacientes HIV soropositivos [tese]. São Paulo: Escola Paulista de Medicina; 1990.

Chimelli PAV, Sofiatti AA, Nunes RS, Martins JEC. Dermatophyte agents in the city of São Paulo, from 1992 to 2002. Rev Inst Med trop S. Paulo. 2003; 45:259-63.

Conti-Diaz IA. Estúdio Micológico de 85 casos de onicopatias. An Fac Med Montevideo. 1964; 49: 535-540.

Coelho MPP, Mendes BG, Soprana H-Z, Santos LFV, Nappi BP, Santos JI. Micoses observadas em pacientes atendidos no Hospital Universitário, Florianópolis, Santa Catarina. RBAC. 2005; 37: 27-30.05

Costa EF, Wanke B, Martins ECS. Micoses superficiais e cutâneas- estudo comparatico entre duas populações: Rio de Janeiro (RJ) a Aracaju (SE). An Bras Dermatol. 1991; 66:119-22.

Costa M, Passos XS, Souza LKH, Miranda ATB, Lemos JA, Junior JGO, Silva MRR. Epidemiologia e etiologia das dermatofitoses em Goiânia, GO, Brasil. Rev Soc Br Med Trop. 2002; 35:19-22.

Dompmartin D, Dompmartin A, Deluol AM, Grosshans E, Coulaud JP. Onychymycosis and AIDS: clinical and laboratory findings in 62 patients. Int $J$ Dermatol. 1990; 29:337-339. 
Doncker P, Daniel CR, Elewski BE. Onychomycosis in children: Prevalence and treatment strategies. J Am Acad Dermatol. 1997; 36: 395-402.

Drake LA, Patrick DL, Fleckman P, André J, Baran R, Haneke E, Sapède C, Tosti $A$. The impacto $f$ onychomycosis on quality of life: development of an international onychomycosis-specific questionnaire to measure patient quality of life. J Am Acad Dermatol. 1999; 41:189-96.

Elewski BE, Greer DL. Hendersonula toruloidea and Scytalidium hyalinum. Arch Dermatol. 1991; 127: 1041-4.

Elewski BE. Onychomycosis caused by Scytalidium dimidiatum. J Am Acad Dermatol. 1996; 35: 336-8.

Elewski BE. Large-scale epidemiological study of causal agents of onychomycosis: mycological findings from the multicenter onychomycosis study of terbinafine. Arch Dermatol. 1997; 133: 1317-8.

Elewski BE. Onychomycosis: pathogenesis, diagnosis, and management. Clin Microbiol Rev. 1998; 11: 415-29.

Ellis DH. Diagnosis of onychomycosis made simple. $J$ Am Acad Dermatol.1999; 40:. 3-8, .

Ellis D.H.; Marley J.E.; Watson A.B.; Williams T. Significance of nondermatophyte molds and yeast in onychomycosis. Dermatology, 1997. 194, (Suppl 1): 40-2.

Ellis D.H.; Watson A.B.; Marley J.E.; Williams T.G. Non-dermatophytes in onychomycosis of the toenails. Br J Dermatol., 1997; 136: 490-3. 
English MP. Invasion of the Skin by filamentous non-dermatophyte fungi. $\mathrm{Br}$ J Dermatol. 1968; 80: 282-6.

English MP. Nails and fungi. Br J Dermatol. 1976; 94:697-701.

Faergemann J, Baran R. Epidemiology, clinical presentation and diagnosis of onychomycosis. Br J Dermatol. 2003; 149 (s65): 1-4.

García-Martos P, Gene J, Solé M, Mira J, Ruiz-Henertrosa R, Guarro J. Case of onychomycosis caused by Microsporum racemosum. J Clin Microbiol. 1999; 37: 258-60.

Gentles JC, Evans EG. Infection of the feet and nails with Hendersonula toruloidea. Sabouraudia. 1970; 8: 72-5.

Ghannoum MA, Hajjeh RA, Scher R, Konnikov N, Gupta KA, Summerbell R, Sillivan S, Daniel R, Krusinski P, Fleckman P, Rich P, Odom R, Aly R, Pariser D, Zaiac M, Bebell G, Lesher J, Gerlash B, Ponce-de-Leon GF, Ghannoum A, Warner J, Isham N, Elewski B. A large-scale North American study of fungal isolates from nails: the frequency of onychomycosis, fungal distribution, and antifungal susceptibility patterns. J Am Acad Dermatol. 2000; 43: 641-8.

Gianni C.; Cerri A.; Crosti C. Non-dermatophytic onychomycosis. An understimated entity? A study of 51 cases. Mycoses. 2000; 43: 29-33.

Greer D.L. Evolving role of nondermatophites in onychomycosis. Int $\mathrm{J}$ Dermatol. 1995; 34: 521-5.

Gupta AK, Sibbald RG, Lynde CW, Hull PR, Prussik R, Shear NH, Doncker P, Daniel III CR, Elewski BE. Onychomycosis in children: Prevalence and treatment strategies. J Am Acad Dermatol. 1997 a; 36: 395-402. 
Gupta AK, Hem CJ, Lynde CW, Watteel GN, Summerbell RC. Prevalence and epidemiology of unsuspected onychomycosis in patients visiting dermatologists offices in Ontario, Canada - a multicenter survey of 2001 patients. . Int J Dermatol. 1997 b; 36:783-7.

Gupta A.K.; Horgan-Bell C.B.; Summerbell R.C. Onychomycosis associated with Onychocola canadesnis: Ten case reports and review of the literature. J Am Acad Dermatol. 1998; 39: 410-7.

Gupta AK, Hem CJ, Lynde CW, MacDonald P, Cooper EA, Summerbell RC. Prevalence and epidemiology of onychomycosis in patients visiting physicians' offices: a multicenter Canadian survey of 15000 patients. J Am Acad Dermatol. 2000; 43: 244-8.

Gupta AK, Cooper EA, MacDonald P, Summerbell RC. Utility of inoculum counting (Walshe and English criteria) in clinical diagnosis of onychomycosis caused by nondermatophitic filamentous fungi. $J$ Clin Microbiol. 2001:9:2115-21.

Gupta A.K.; Ryder J.E.; Summerbell R.C. The diagnosis of nondermatophyte mold onychomycosis. Int. J. Dermatol. 2003; 42: 272-3.

Gupta A.K.; Sibbald G.; Lynde C.W.; Hull P.R.; Prussick R.; Shear N.H.;

Habbif TP. Doenças das Unhas. In: Habbif TP. Dermatologia clínica 4a ed. Porto Alegre: Artmed. 2005.

Hay RJ, Baran R, Haneke E. Fungal (onychomycosis) and other infections involving the nail apparatus. In: Baran R, Dawber RPR. Diseases of the nails and their management. 2a ed. 1994. 97-133. Chapter 4 
Haneke E. Fungal infections of the nail. Semin Dermatol. 1991; 10: 41-53.

Heikkilä $\mathrm{H}$, Stubb S. The prevalence of onychomycosos in Finland. $\mathrm{Br} \mathrm{J}$ Dermatol. 1995;133:699-703.

Hennequin C, Lavarde V, Poirot JL, rabodonirina M, Datry A, aractingi S, Dupouy-Camet J, Caillot D, Grange F, Kures L, Morin L, Lebeau B, Bretagne S, Guigen C, Basset D, Grillot R. Invasive Fusarium infections: a retrospective survey of 31 cases. J Med Vet Mycol. 1997; 35: 107-14.

Ivanir I, Sahin MT, Guündüz K, Dinç G, Türel A, Arisoy A, Öztürkcan S. Case report. Tinea pedis in primary scholl children in Turkey. Mycoses. 2002; 45: 198-201.

Kemna ME, Elewski BE. A U.S. epidemiologic survey of superficial fungal diseases. J Am Acad Dermatol. 1996; 35: 539-42.

Koussidou T, Devliotou-Panagiotidou D, Karakatsanis G, Minas A, Mourellou O, Sâmara K. Onychomycosis in Northern Greece during 1994-1998. Mycoses. 2002; 45:29-37.

Krosravi AR, Mansouri P. Onychomycosis in Tehran, Iran: Prevailing fungi and treatment with itraconazole. Mycopathologia. 2000; 150: 9-13.

Lacaz CS, Pereira AD, Heins-Vaccari EM, Cucé LC, Benatti C, Nunes RS, Melo NT, Freitas-Leite RS, Hernandéz-Arriagada GL. Onychomycosis caused by Scytalidium dimidiatum. Report of two cases. Review of the taxonomy of the synanamorph and anamorph forms of this coelomycete. Rev Inst Med Trop S Paulo. 1999; 41: 319-23.

Lacaz C.S.; Porto E.; Martins J.E.C.; Heis-Vaccari E.M.; Melo, N.T. Tratado de Micologia Médica. São Paulo: Sarvier. 2002. 
Lacroix C, Kac G, Dubertret L, Morel P, Derouin F, Chauvin MF. Scytalidiosis in Paris, France. J Am Acad Dermatol. 2003; 48: 852-6.

Lim JT-E, Chua HC, Goh CL. Dermatophyte and non-dermatophyte onychomycosis in Singapore. Australas J Dermatol. 1992; 33: 159-63.

Lopes JO, Alves SH, Mari DRD, Oliveira LTO, Brum LM, Westphalen JB, Furian FW, Altermann MJ. A ten-year survey of onychomycosis of the Rio Grande do Sul, Brazil. Rev Inst Med trop S. Paulo. 1999; 41:147-9.

Martelozo IC, Guilhermetti E, Svidzinski TIE. Ocorrência de onicomicose em Maringá, Estado do Paraná, Brasil. Acta Sci. Health Sci. 2005; 27: 177-182.

Merz WG, Karp JE, Hoagland M, Jett-Goheen M, Junkins JM, Hood AF. Diagnossis and successful treatment of fusariosis in the compromised host. $J$ Infect Dis. 1988; 158: 1046-55.

Midgley G, Moore M, Cook JC, Phan QG. Mycology of nail disorders. J Am Acad Dermatol. 1994; 31: S68-S74.

Moore MK. Hendersonula toruloidea and Scytalidium hyalinum infections in London, England. J Med Vet Mycol. 1986; 24: 219-30.

$\mathrm{Ng} \mathrm{KP}$, Sôo-Hoo TS, Na SL, Ang LS. Dermatophytes isolated from patients in University Hospital, Kuala Lumpur, Malaysia. Mycopathologia. 2001; 155: 203-6.

Oliveira JC. Avaliação de novas técnicas diagnósticas em Onicomicoses [tese]. Rio de Janeiro: Fundação Oswaldo Cruz; 2001.

Philpot, Cm; Shuttleworth D. Dermatophyte onychomycosis in children. Clin Exp Dermatol. 1989; 14: 203-5. 
Porro AM, Yoshioka MCN. Manifestações dermatológicas da infecção pelo HIV An bras Dermatol. 2000; 75: 665-91.

Ruiz LRB, Zaitz C. Dermatófitos e dermatofitoses na cidade de Sao Paulo no eriodo de agosto de 1996 a julho de 1998. An Bras dermatol. 2001; 76:391401.

Piraccini BM, Tosti A. White superficial onychomycosis. Epidemiological, clinical, and pathological study of 79 patients. Arch Dermatol. 2004; 140: 696-701.

Pontarelli LN, Hasse J, Galindo CC, Coelho MPP, Nappi BP, Santos JI. Onychomycosis by scytalidium dimidiatum: report of two cases in Santa Catarina, Brazil. Rev. Inst. Med. trop. S. Paulo. 2005; 47: 351-3.

Porto E, Takahashi N, Heins Em, Lacaz C Da S. Nuevo metodo para microcultivo de hongos. Rev. argent. Micol. 1981, 4: 24-9.

Ramesh V, Reddy BSN, Singh R. Onychomycosis. Int J Dermatol. 1983; 22:14852.

Roberts DT. Prevalence of dermatophyte onychomycosis in the United Kingdom: results of an omnibus survey. Br. J. Dermatol. 1992; 126: 23-7.

Sais G, Jucglà A, Peyrí J. Prevalence of dermatophyte onychomycosis in Spain: a cross-sectional study. Br. J. Dermatol. 1995; 132: 758-61.

Sampaio SAP, Riviti EA. Micoses superficiais. In: Sampaio SAP, Rivitti EA Dermatologia. São Paulo: Artes Médicas; 1998

ScherRK. Onychomycosis is more than a cosmetic problem. Br. J. Dermatol. 1994; 130: 15. 
Simonetti O, Bernardini ML, Arzeni D, Cellini A, Barchiesi F, Offidani A. Epidemiologia of onychomycosis and paronychia in the área of Ancona (Italy) over a period of 5 years. Mycopathologia. 2004; 158: 271-4.

Siqueira ER, Ferreira JC, Maffei CML, , Candido RC. Ocorrência de dermatófitos em amostras de unhas, pés e mãos coletadas de estudantes universitários. Rev Soc Bras Med Trop. 2006; 39: 269-71.

Srinivas CR, Ramain A, Kumari TGR, Shivananda PG. Molds in onychomycosis. Int J Dermatol. 1993; 32: 877-8.

Summerbell RC. Epidemiology and ecology of onychomycosis. Dermatol. 1997; 194: 32-6.

Summerbell RC, Cooper E, Bunn U, Jamieson F, Gupta AK. Onychomycosis: a critical study of techniques and criteria for confirming the etiologic significance of nondermatophytes. Med Micol. 2005; 43: 39-59.

Summerbell, Rc; Kane, J; Krajden,S. Onychomycosis, tinea pedis and tinea manuum caused by non-dermatophytic filamentous fungi. Mycoses; 32:60919, 1989.

Tosti A.; Piraccini, B.M.; Lorenzi S. Onychomycosis caused by nondermatophytic molds: Clinical features and response to treatment of 59 cases. J Am Acad Dermatol. 2000; 42: 217-24.

Walshe MM, English MP. Fungi in nails. Br. J. Dermatol. 1966; 78:198-207.

Weinberg JM, Koestenblatt EK, Tutrone WD, Tishler HR, Najarian L. comparison of diagnostic methods in the evaluation of onychomycosis. $\mathrm{J} \mathrm{Am}$ Acad Dermatol. 2003; 49: 193-7. 
Williams HC. The epidemiology of onychomycosis in Britain. Br. J. Dermatol. 1993; 129: 101-9.

Zaias N. Superficial white onychomycosis. Sabouraudia. 1966; 5: 99-103.

Zaias N. Onychomicosis. Arch Dermatol. 1972; 105: 263-74.

Zaias N. Clinical manifestations of onhychomycosis. Clin Exp Dermatol. 1992; 17: 6-7.

Verzignassi JR, Poltronieri LS, Benchimol RL, Moura MF. Scytalidium lignicola causando manchas em folhas, hastes e frutos de baunilh. Fitopatol brás. 2007, 32:84.

Vilela NA, Sotão H, Calil F. Onicomicose por Microsporum canis: ocorrência em indígenas do norte do Estado de Goiás. Rev Pat Trop. 1991; 19: 43-5. 